\title{
ARQUITECTURA Y PODER: EL DISCURSO VISUAL DEL NO-DO Y LA ARQUITECTURA DEL FRANQUISMO (1943-1975)

\author{
NOEMÍ RUBIO POZUELO
} \\ Universidad de Córdoba
}

\begin{abstract}
Resumen
Hoy podemos considerar el NO-DO como una fuente de inestimable valor para la investigación histórica en todos sus ámbitos. Este noticiario que se desarrolló paralelamente al franquismo se instrumentalizó al servicio del régimen, una cuestión ésta que pierde sus connotaciones negativas cuando - como es el caso de este artículo - lo tratamos como fuente de información. En concreto la representación que hizo el Noticiario NO-DO de la producción arquitectónica supone un testimonio de gran relevancia para la Historia del Arte. "Interrogar" las diferentes imágenes arquitectónicas nos permite profundizar cómo se construye la huella de la arquitectura española del momento, desde una perspectiva cuando menos singular.
\end{abstract}

\section{Palabras clave}

Noticiario NO-DO, Arquitectura franquista, Arquitectura española, Documental de Arquitectura

Arquitecture and power: the visual discourse of NO-DO and the arquitecture of francoism (1943- 1975)

\section{Abstract}

Today we can consider NO-DO as a source of inestimable value for historical research in all its areas. This news program that developed parallel to the Franco regime was instrumented in the service of the regime, an issue that loses its negative connotations when - as is the case of this article - we treat it as a source of information. In particular the representation made by the NO-DO News of the architectural production is a testimony of great relevance for the History of Art. "Interrogar" the different architectural images allow us to deepen how the footprint of Spanish architecture of the moment is constructed, from a perspective when less singular.

Key words

Newsreel NO-DO, Franco Architecture, Spanish architecture, Documentary architecture.

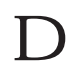


La huella del NO-DO.

La proyección del Noticiario Documental NO-DO representó una ventana por la que la sociedad española podía asomarse al mundo en los años que duró la dictadura franquista. Este documental de carácter informativo fue el portador de noticias nacionales e internacionales de manera semanal, por lo que produjo un gran volumen de información que hoy supone una fuente histórica de gran riqueza, aportando una visión de extraordinario valor, aunque ésta pueda resultar sesgada.

De los variados y abundantes temas de los que se ocupó NO-DO ${ }^{1}$ queremos destacar el papel que desempeñó la producción arquitectónica, pues la consideramos más que un mero figurante de la diégesis de este documental. Los diferentes testimonios arquitectónicos que en él se recogen se presentan como los protagonistas indiscutibles de una parte fundamental de la historia española. Al posar nuestra mirada en la gran propuesta de reconstrucción arquitectónica que se llevó a cabo en España en los años que duró la proyección, observamos como las imágenes registradas por la cámara nos muestran una huella singular, es la huella de quien ha sido testigo "silencioso" de ideologías, política, economía, ideas y valores estéticos y vida social, entre otros. Su visión se destacó por ser particular y monopolista con la información que se producía en España y para España, pero también para el extranjero, cuestión que se refleja en una de sus mayores máximas: "el mundo entero al alcance de los españoles". Una obra tan compleja como es el NO-DO nos plantea un gran abanico en cuanto a multiplicidad de lecturas; de ellas se derivan cuestiones como: ¿cuál es el papel que cumplió la arquitectura en el contexto del NO-DO?, ¿cuáles son los principios que revela?, o ¿hasta qué punto influyó al régimen o estuvo al servicio de éste?. Estas y otras cuestiones nos conducen a observar la imagen de este noticiario como testimonio de una época concreta, las cuales no sólo dialogan acerca de lo que vemos sino también de lo que no vemos, de ahí el valor incalculable del NO-DO como fuente para la historia, como afirma Sánchez Biosca: "El NO-DO es un lugar de la memoria que reclama ser estudiado, es el ojo de la historia del franquismo".

La Arquitectura como herramienta de reconstrucción nacional.

Los estudios que se han realizado hasta ahora sobre la arquitectura española durante el franquismo se han centrado principalmente en Madrid como capital; el resto siguen el mismo esquema que los anteriores, centrándose en las particularidades de cada lugar; pero Madrid se destaca entre las demás por ser la capital del país, y porque por ella debían comenzar los nuevos cambios. De este modo, la ciudad madrileña sirvió como banco de pruebas para las políticas de reconstrucción, planes urbanísticos y los primeros planes de viviendas.

Lo inmediato concluida la guerra fue la reconstrucción de las ciudades más afectadas. Esto se concretó en la recuperación de inmuebles que todavía podían ser usados, dando lugar a una nueva arquitectura que sería la nueva seña de identidad del régimen. Este modelo arquitectónico, seña de identidad de la nueva realidad española, se encontró con diversos obstáculos. Por un lado, en España existía una crisis previa al conflicto bélico, que se agudizó con el mismo, y esto influyó directamente en una renovación que era necesaria para la arquitectura después de la Guerra Civil. El desarrollo en el quehacer arquitectónico que vino con posterioridad creció aislado de las influencias externas que hubieran permitido el acercamiento a las nuevas corrientes que se estaban dando en la arquitectura europea y norteamericana, y que reflexionaban en torno a usos, funciones nuevas y espacios habitables de la arquitectura, entre otros aspectos.

Además la férrea política del régimen estableció un aislamiento en todos los sentidos, imposibilitando que los arquitectos del momento no sólo no pudieran tener acceso a las últimas noticias en su ámbito de acción, sino que tampoco lograran aproximarse a los últimos

\footnotetext{
${ }^{1}$ NO-DO: Este trabajo ha sido facilitado por el acceso online a la página de RTVE y al Archivo Histórico del NO-DO, a través de la página web de la Filmoteca Española, que permite la consulta a todas las ediciones realizadas de los noticieros. Salvo en algunos pocos números de los que no se conservan negativos ni copias.
}

${ }^{2}$ SÁNCHEZ BIOSCA/ TRANCHE, 2000: El Nodo el Tiempo y la Memoria, p.242. 
avances tecnológicos, cuestión que se agudizó aún más cuando años más tarde España quedó aislada desde el exterior tras el triunfo de los Aliados en la II Guerra Mundial. Por lo tanto, los medios con los que contó la primera arquitectura de posguerra fueron escasos, lo que supuso un panorama difícil para aquellos arquitectos a los que se les comenzaba a encargar nuevos proyectos y que tenían como fin la tan proclamada reconstrucción de España. Rojo de Castro señala a este respecto que la España de ese momento se regodeó en "un estado amnésico del pasado reciente, buscando un renacimiento ideológico que hacía grande a España, aunque para eso fuese necesario falsificar el presente", de ahí que este autor denomine a la arquitectura de este periodo como "apócrifa". ${ }^{3}$

El principal problema con el que se encontró la reconstrucción de España fue la escasez de vivienda. Siendo el contexto enormemente crítico y adverso. A la pérdida de muchos edificios de uso doméstico a lo largo de la contienda, hay que unir los movimientos de migración interior. ${ }^{4}$ La población huía de contextos marginales y destruidos por el reciente conflicto y buscaba seguridad económica y social. Fue con la Ley de 19 de abril de 1939 cuando se otorgó una definición legal al concepto de vivienda protegida, incluyendo diferentes variantes, como la vivienda mínima y las viviendas para militares o funcionarios. ${ }^{5}$ En 1954 se aglutinaron estas categorías, con el objetivo de garantizar la existencia de vivienda de renta mínima. La prioridad fue perseguir que la nueva arquitectura supliera las necesidades más básicas de alojamiento, no planteándose mayores esfuerzos en cuanto a concepto o diseño. Los resultados de este esfuerzo dieron sus frutos, aunque escasos dadas las circunstancias no había mano de obra cualificada, recursos, etc. - así entre 1939 y 1950 se construyeron una media de 50 viviendas por provincia y año, números alejados de lo que la realidad requería. Consecuencia de ello es la disposición por parte del régimen de un plan que erradicara las carencias en materia de vivienda, para lo cual se crearon una serie de organismos contemplados como unidades administrativas, al frente de ellas estuvo un cuerpo técnico que como era natural, fue afín al régimen y abordó su cometido contemplando "el valor simbólico de la arquitectura como herramienta de reconstrucción nacional". ${ }^{6}$

Uno de estos organismos administrativos y políticos fue el Instituto Nacional de Vivienda (INV), siendo su primer director Federico Mayo. Este ente era el promotor principal de los proyectos de construcción de viviendas de renta reducida, resultantes de subvenciones y ayudas de diversa índole, y su función principal fue la de redactar los Planes Nacionales de Vivienda. En 1939, este Instituto redactó un reglamento que incorporaba especificaciones técnicas, constructivas y administrativas, e incluso contempló un programa de necesidades de carácter básico. Diez años más tarde, José Antonio Girón de Velasco redactó el I Plan Nacional de Vivienda, que dio como resultado lo que hoy se conoce como "la revolución de las casas baratas", que fue encargado al Instituto Nacional de Vivienda y a la Obra Sindical del Hogar. ${ }^{7}$

Desde la Dirección General de Arquitectura (D.G.A.), se impulsó también las construcciones de obra nueva destinada a vivienda. Este organismo tuvo un instrumento muy relevante en lo que se refiere a los cambios arquitectónicos que comenzaron a darse a finales de los años cuarenta y principios de los cincuenta, fue el Boletín que promovió esta Dirección. En él se mostraban los avances de la renovación arquitectónica provenientes de las corrientes externas. Fueron sus directores arquitectos como Francisco Prieto Moreno, que fue el Direc-

\footnotetext{
${ }^{3}$ ROJO DE CASTRO, 2003: La vivienda en Madrid durante la Posguerra 1939-1949, p. 243.

${ }^{4}$ Los datos que se reflejan en el Instituto Nacional de Estadística hablan de cambios considerables en la densidad de población, sobre todo en los números de habitantes de municipios de más de 10.000 habitantes, pasándose de una población total de 23.667.095 habitantes en 1930 a 28.117.873 en 1950, es decir la población de los municipios de más de 10.000 habitantes aumentó en una media de 4.497 .705 personas.

${ }^{5}$ LÓPEZ DÍAS, 2003; Vivienda Social y Falange: Ideario y construcciones en la década de los 40, p.2.

${ }^{6}$ ROJO DE CASTRO, 2003; La vivienda en Madrid durante la Posguerra 1939-1949, p. 228.

${ }^{7}$ GARCÍA VÁZQUEZ, 2015: La obsolescencia de las tipologías de viviendas de los polígonos residenciales construidos entre 1950 y 1976 , pp.2-3.
} 
tor General de la DGA y Carlos de Miguel quien ostentó la dirección de la Revista Nacional de Arquitectura; junto a ellos destacó el arquitecto José Luís Arrese, uno de los principales teóricos del franquismo en sus primeros momentos y el primer Ministro de la Vivienda (1941-1945). ${ }^{8}$

La función principal de promover y construir Viviendas Protegidas de Renta Reducida estuvo a cargo de la Obra Sindical del Hogar (OSH), que contó con el apoyo directo de la Falange Española, ${ }^{9}$ que impulsó un replanteamiento en las políticas de vivienda social, empleando la arquitectura como un campo de lucha social. La Falange propuso modelos de vivienda que se oponían a la segregación social. Rechazaba llevar la diferenciación de clases a la arquitectura. La Falange Española propuso como algo novedoso construir barrios en los que pudiera residir cualquier persona, rechazando en la zonificación urbana la habitual lucha de clases. ${ }^{10}$ Aunque también es cierto que quisieron combatir muchos de las ideas que el racionalismo había venido promulgando, su intervención en la arquitectura española por la igualdad social en el ámbito de la vivienda, fue positiva, fue el cambio hacia la reflexión de las necesidades reales a las que se enfrentaba una familia cuando accedía a una vivienda. La Falange Española utilizó la lucha por una vivienda digna, para difundir la idea de hogar español como "el centro de expansión del espíritu, el marco que encuadra la familia" sustituyendo así el concepto de la arquitectura como algo frío e inerte. El modelo de los idealizados barrios que proponía La Falange no permaneció en el tiempo, es en la década de los cincuenta cuando comienza a implantarse el modelo de los polígonos residenciales.

Este organismo creado en $1939^{11}$ contó con una plantilla de arquitectos afines a su ideología nacional socialista. Al frente de ella Pedro Muguruza, difusor del modelo de la arquitectura impulsada por el Régimen, a quien se le encargó la reorganización de la arquitectura nacional y estuvo al frente de la Dirección General de Arquitectura (D.G.A). ${ }^{12}$ Otros arquitectos fueron el citado José Luis Arrese, Pedro Bidagor, ${ }^{13}$ al que se le encargó el proyecto germen del Plan General de Ordenación de Madrid, conocido como Plan Bidagor. Francisco Asís Cabrero, Rafael de Aburto, José Antonio Cordech o Iñiguez de Onzoño, todos ellos desempeñaron una importante labor dentro de la O.S.H.

El Servicio Nacional de Regiones Devastadas y Reparaciones, que inició su andadura en 1938, su objetivo fue la reconstrucción de las zonas denominadas como liberadas; posteriormente pasó a formar parte del Ministerio de Gobernación denominándose Dirección General de Regiones Devastadas y Reparaciones (DGRDR). Al frente de este organismo estuvo José Moreno Torres, quien también fue nombrado Director de la Junta de Reconstrucción. La tarea primordial que tuvieron que acometer sendos organismos fue la reparación de las viviendas que estaban en malas condiciones de habitabilidad y la construcción de albergues a la espera de las nuevas viviendas.

${ }^{8}$ PÉREZ ESCOLANO, 2014: Arquitectura y política en España a través del "Boletín de la Dirección General de Arquitectura"1946-1957, p.35

9 ROJO DE CASTRO, L; Op. cit, p. 230.

${ }^{10}$ LÓPEZ DÍAS, 2003: Vivienda Social y Falange: Ideario y construcciones en la década de los 40, p.3.

${ }^{11}$ GUTIÉRREZ MOZO/CARO GALLEGO, 2003: La arquitectura de la Obra Sindical del Hogar en la ciudad de Albacete: 1941-1981, p.125.

${ }^{12}$ LÓPEZ DÍAS, 2003; Op.cit., p4.

13 SAMBRICIO, C; La vivienda en Madrid, de 1939 al Plan de Vivienda Social, p.14: En Junio 1939 Bidagor intervino en la I Asamblea Nacional de Arquitectos y planteó su propuesta de ciudad. En este plan hacía referencia a la necesidad de un sistema de alineaciones, criticando la desorganización de las funciones urbanas, su propuesta incluía trazar las nuevas ciudades de acuerdo a fines políticos y económicos, incluyendo fines sociales cuyo objetivo era el aumento de la calidad de vida. 
Fruto del trabajo de muchos años se consiguió la recuperación de algunos de los edificios emblemáticos, de barriadas e incluso de poblados completos. ${ }^{14}$

La planificación arquitectónica estuvo también contenida en los diferentes planes, tanto a nivel nacional como regional, así en materia de urbanismo; se quería evitar un crecimiento descontrolado, por ello se estableció un sistema de planificación de anillos verdes que se adaptaran a su geografía. El gran problema al que se tuvieron que enfrentar fue al crecimiento de los suburbios, que proliferaban en el extrarradio y que se presentaban en muchos casos como un aspecto difícil de controlar.

En el ámbito rural también se hizo necesaria una nueva arquitectura que se ajustara a las necesidades en este medio, con este fin se formó el Instituto Nacional de Colonización (INC), creado en $1939 .{ }^{15}$ El objetivo principal de este organismo fue el de repoblar grandes zonas de tierra baldías. El modo de proceder habitual fue la entrega a familias desfavorecidas de una vivienda y una porción de tierra destinada a la agricultura, los terrenos podían ser de regadío o secano, a cambio se les requería un porcentaje alto de las ganancias obtenidas en la cosecha. Aunque las viviendas representaron una mejora sustancial para las familias, en algunos casos el rédito que había que entregar suponía no tener apenas ingresos. Desde el punto de vista arquitectónico esta Institución, estuvo formada por jóvenes arquitectos como José Luis Fernández del Amo, Antonio Fernández Alba, Alejandro de la Sota, y José Antonio Corrales, estuvieron influenciados por las nuevas tendencias en este tipo de modelo de arquitectura social y rural, como fueron los casos de Italia o Israel, ${ }^{16}$ lo que sirvió para dotar de una nueva imagen al paisaje rural que había estado desierto.

En los años cincuenta se puede observar una arquitectura más depurada y pensada según otros parámetros y se comienza a profundizar en la reflexión sobre el problema de las viviendas sociales, factor derivado en gran medida del crecimiento económico de aquellos años, y que permitió al proceso constructivo agilizarse eficientemente. A este respecto Sambricio reconoce que 1954 "fue un punto de inflexión en cuanto a la valoración de la vivienda social" en medio de la reconstrucción; ${ }^{17}$ el hecho de que el país tuviera un déficit elevado y la existencia de más de cuatrocientas mil chabolas influyó también en este hecho, pues se hacía necesario pensar más en cantidad a la hora de construir que en calidad. ${ }^{18}$ En esta nueva arquitectura destacaron arquitectos como Sáez de Oiza, Alejandro de la Sota, Molezún, Gutiérrez Soto, o Miguel Fisac, muchos de ellos constituyen hoy el testimonio de la ruptura con los modelos anteriores, pero no podemos olvidarnos de otros arquitectos que también aportaron un generoso ejemplo en los avances que se estaban dando en arquitectura. Como afirma Sambricio en muchos casos estos nombres han sido olvidados o por lo menos no tratados con la misma relevancia. Autores como Román y Cubillo, Domínguez Salazar, Rafael de la Hoz, y Fernández del Amo destacaron por su buen hacer en la arquitectura española. ${ }^{19}$

Aunque es evidente que la mayoría de todos los esfuerzos de nueva obra venían dados por la necesidad de nueva vivienda para los españoles, también era necesario dotar de nuevas infraestructuras que atendieran las necesidades en materia de educación y sanidad, entre otros. La guerra no sólo había dejado a su paso un paisaje urbano devastador, sino que también quedó patente la ausencia de dichas infraestructuras. A este respecto Sambricio recoge parte de la investigación realizada por Paz Maroto, en la cual ella afirma que fueron precisamente

\footnotetext{
${ }^{14}$ ROJO DE CASTRO, 2003: Op. cit, p. 228.

${ }^{15}$ RABASCO POZUELO, 2011:“Las influencias extranjeras en la arquitectura y urbanismo en el Instituto Nacional de Colonización”, Universidad de Córdoba, p.254

${ }^{16}$ RABASCO POZUELO, 2011: Ibíd., pp. 255-256.

${ }^{17}$ SAMBRICIO, 2000: "La vivienda española en los años 50: la arquitectura española y su compromiso con la historia". Escuela Técnica Superior de Arquitectura de la Universidad de Navarra, p. 46.
}

${ }^{18}$ GARCÍA VÁZQUEZ, 2015:“La obsolescencia de las tipologías de viviendas de los polígonos residenciales construidos entre 1950 y 1976. Desajustes con la realidad sociocultural contemporánea”, p.4.

${ }^{19}$ SAMBRICIO, 2000: “La vivienda en Madrid, de 1939 al Plan de Vivienda Social, 1959”, pp.13-14. 


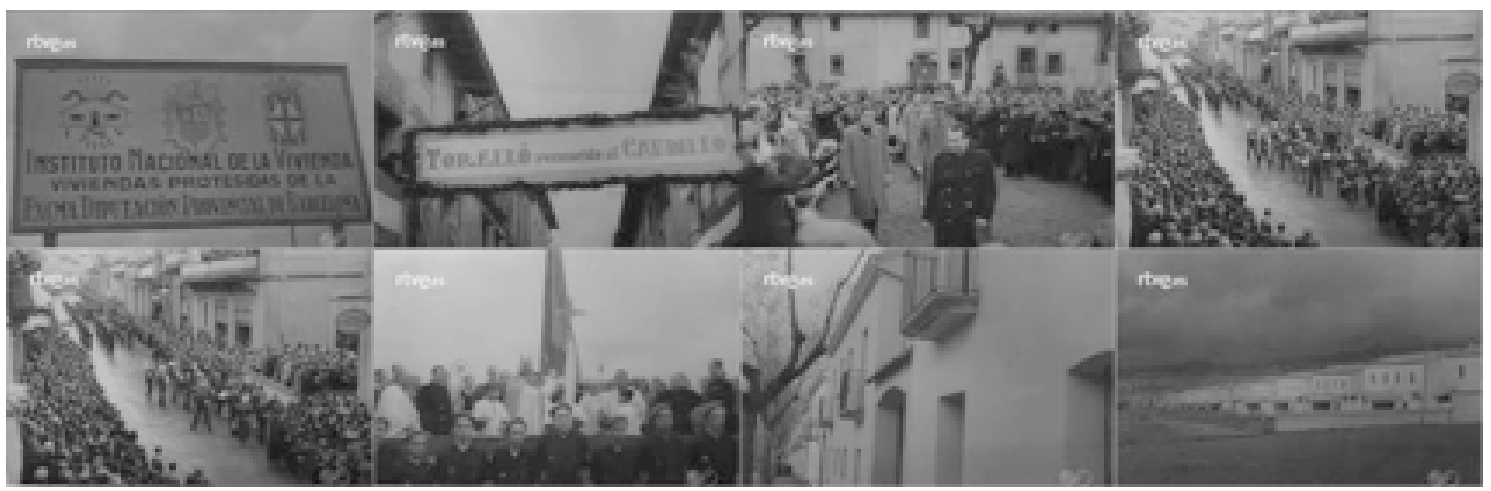

Sec. 1. Secuencia de planos del capítulo NOT N 16, abril, 1943. Capturas realizadas en la página del Archivo NO-DO

las destrucciones de la guerra las que de alguna manera vinieron a justificar la construcción de una infraestructura que ya era inexistente previamente a la guerra, ayudando así a mejorar cuestiones como el alumbrado y alcantarillado. No es hasta bien entrados los años cuarenta cuando se comienzan a construir sanatorios y hospitales, muchos de ellos con los últimos avances tecnológicos en medicina. Estos edificios se vieron acompañados de nuevas escuelas y residencias para niños en circunstancias desfavorables. Poco a poco se fue recomponiendo el paisaje que había estado huérfano de edificios con los mejores avances, y la arquitectura no se olvidó de los grandes edificios institucionales que aparte de suplir una cuestión funcional y necesaria, se proyectaban como símbolos del espíritu del régimen de Franco.

En 1955 España es admitida en la ONU, y esto trajo consigo un despeje del aislamiento que había experimentado el país hasta el momento. Con el discurrir de los años se fue experimentando en la arquitectura española una cierta apertura hacia nuevas corrientes, debido sobre todo al papel que desempeñaron las revistas nacionales de temática arquitectónica. Estas publicaciones cuestionaron el papel del arquitecto en la sociedad planteando que la arquitectura es algo más que la solución a un problema concreto. Revistas como "Hogar y Arquitectura", la Revista del Colegio Oficial de Arquitectos de Madrid, que se llamó "30D" (30 días de arquitectura), o la Revista "Nueva Forma", dirigida por Juan Daniel Fullaondo, fueron publicaciones destacadas en el panorama español, pero sobre todo la publicación que dirigía Fullaondo ${ }^{20}$ llegaron algunas influencias a España de grupos de arquitectura como Architecture Principe que aportaron conceptos tan relevantes como la function oblique así como su definición de órdenes urbanos. ${ }^{21}$ Otro reflejo de cambios fue la influencia de la corriente megaestructural que buscaba sus referentes en su pasado inmediato y a su vez depositaba interés en el movimiento futurista, lo que supuso un enfoque muy enriquecedor para la arquitectura española. Gracias a estas influencias llegó un momento en el que el pensamiento de la nueva arquitectura española giraba en torno a la expresividad estructural para posteriormente poder habitar la estructura. Aunque es cierto que estas manifestaciones se dieron con cierto desfase con respecto al resto de la escena europea, la arquitectura española se enriqueció de este movimiento, así tenemos ejemplos en la obra de Francisco Javier Sáenz p. 77 .

${ }^{20}$ PÉREZ MORENO, 2014: Claude Parent en Nueva Forma: La recepción de Architecture Principe España,

${ }^{21}$ Mientras que el orden urbano horizontal trata sobre la conquista del suelo y tierra, el orden urbano vertical ejemplifica la conquista del espacio aéreo, abstracto y mítico. Estas reflexiones permitían la convivencia entre la masiva circulación de la ciudad que sería el orden horizontal, con el espacio habitable que vendría asimilarse como el orden vertical. En cuanto a la función oblicua Pérez Moreno señala que surgió como una crítica a los planteamientos urbanos identificados con la conciencia moderna, y ella la define como una berramienta conceptual capaz de formalizar arquitectónicamente un discurso teórico genuino que, por un lado, pretendía revisar la bistoria de los órdenes urbanos y su modo de apropiación espacial, y por otro, proponía un nuevo modo de entender la relación entre el individuo y su entorno físico y cultural. 


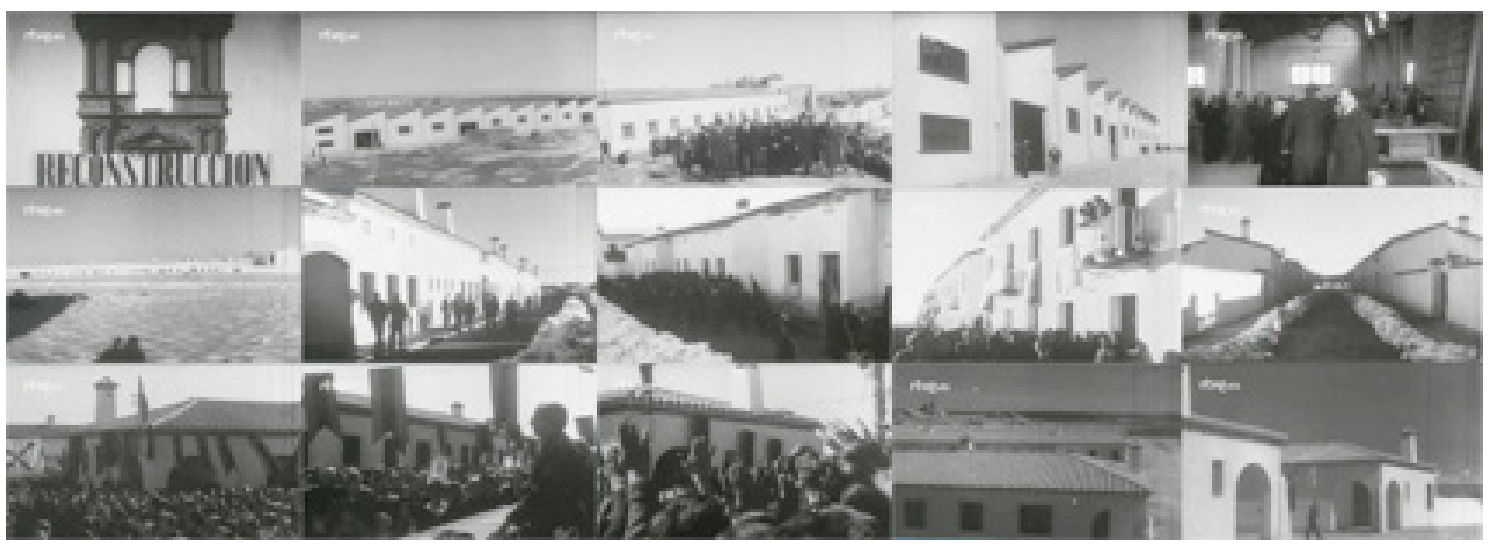

Sec.2. Secuencia de planos del capítulo NOT N 66- A, abril, 1944. Capturas realizadas en la página del Archivo NO-DO.

de Oiza, José Luis Romaní, Eduardo Torroja, o Emilio Pérez Piñero.

Ya en los años setenta se dejaron sentir los nuevos avances, y poco a poco la arquitectura se fue liberando de cierto peso del pasado, pero todavía quedaban retos por asumir. Con la muerte de Franco en 1975 el ambiente en general comenzó a cambiar, y el proceso de institucionalización de la arquitectura fue alejándose cada vez más hacia el sector privado. Indudablemente los años del franquismo nos entregaron un testimonio de una arquitectura en deuda con el régimen, así como el régimen está en deuda con ella.

La imagen de la arquitectura española.

Rasgos de la Producción del NO-DO.

Antes de la existencia del NO-DO, se proyectaban en los cines españoles tres noticieros de origen extranjero, FOX, LUCE, y UFA. Con la creación del noticiero franquista (1942) se comunicó a las productoras extranjeras la intención de crear un noticiero propio y en régimen de exclusividad, que se valdría de un acuerdo de colaboración el cual permitirá al medio nacional reproducir las imágenes de estas agencias extranjeras censurándolas según los criterios del propio noticiario. Como resultado la FOX y la UFA aceptaron las condiciones mientras que LUCE las rechazó. ${ }^{22}$

El camino de este noticiario no estuvo exento de cambios desde que el 17 de diciembre de 1942 fuese constituido como un informativo cinematográfico de carácter semanal y de proyección exclusiva de noticias nacionales e internacionales, pues dependió de diferentes Ministerios que se encargaron de su gestión. Así en 1951 pasó a formar parte del nuevo Ministerio de Información y Turismo, y cuando desapareció la Dirección General de Cinematografía se enmarcó dentro de la Dirección General de Radiodifusión y Televisión. Grandes profesionales como Alberto Reig, Díez Alonso, Matías Prats Antolín, y Miguel Martín guiaron el noticiario. Su declive anunciado con la entrada de la televisión en las casas de los españoles se agudizó con la eliminación de la exclusividad y obligatoriedad en todos los cines españoles. El NO-DO desarrolló una trayectoria importante y llegó a producir más de cuatro mil ediciones que suponen unas 700 horas de noticias. La distribución de los diferentes capítulos fue facilitada mediante una clasificación en series, A y B, añadiéndose la serie C a partir de $1960 .{ }^{23}$ La duración de cada capítulo es de aproximadamente 10 minutos, y esta cuestión

${ }^{22}$ GARCÍA GONZÁLEZ, 2015: Y Castilla se hizo España...Nacionalización y Representación Cinematográfica de Castilla en el NO-DO, p.256.

${ }^{23}$ RAMÍREZ MARTÍNEZ, 2008: Ciencia, Tecnología y propaganda. El NO-DO, un instrumento de popularización de la ciencia al servicio del Estado, 1943-1964, p.255. 


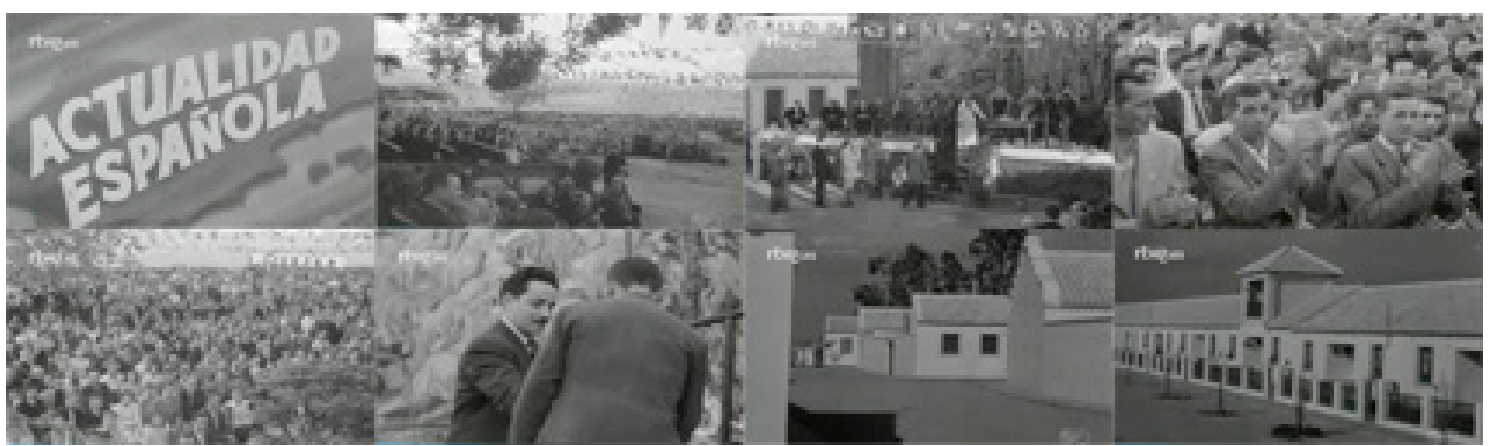

Sec. 3. Secuencia de planos del capítulo. NOT N 336-A, junio 1949. Capturas realizadas en la página del Archivo NO-DO.

unida a la lenta producción de cada capítulo, y a las pocas copias que se distribuían, supuso que la información que se proyectara en los cines no siempre fuera actual.

El elenco de particularidades de las que hace gala este noticiero es abundante; primeramente no podemos olvidar que el NO-DO se convirtió en un elemento creador de opinión, ${ }^{24}$ así como en una máquina de construcción de imágenes ${ }^{25}$ es decir, influyó directamente en la idea de vida cotidiana que tenían los españoles. Por otro lado, el lenguaje codificado y triunfalista, con voces sobreactuadas cargadas de adjetivos y en un castellano modulado sin identidad, refleja la tarea principal del locutor: reconquistar todo aquello que se había perdido. Como afirma Sánchez Biosca es la "exaltación exacerbada del espíritu español”. Otro rasgo de identidad de este noticiario radica en la construcción de imágenes, en las que no se intuye siquiera ninguna jerarquización de noticias, todas discurren, por lo que, como afirma Gloria García Sánchez, no se puede ni intuir una estructura narrativa. Las diferentes imágenes de procedencia y carácter muy diferente se proyectan en la pantalla sin un criterio y orden aparente, aunque nosotros sí que hemos observado una preferencia por ciertas noticias nacionales antes que las extranjeras, sobre todo, en los capítulos donde confluyen información nacional y extranjera al mismo tiempo, se observa en la mayoría de los casos como el código empleado en las imágenes subraya el triunfalismo del locutor, así los ángulos, la toma de edificios, personas, fiestas, todo queda recogido desde un lugar común. Las identidades que capta la cámara son recogidas de un modo peculiar, pareciendo que únicamente son necesarios los altos cargos civiles o eclesiásticos. Estas últimas identidades se contraponen con el mayoritario uso de la masa, que en el noticiario español es la protagonista indiscutible, y esto permite mostrarnos - más allá del deseo propio del NO-DO - una realidad de la sociedad española del momento, evidenciándose en este sentido que "toda forma cinematográfica es el espejo de la sociedad en la cual se elabora". ${ }^{26}$

Como es de suponer la propaganda ideológica formó parte de las características de este documental, pero como afirma Sánchez Biosca, esto debe ser visto desde el contexto donde se desarrolla este noticiario. Si es cierto que fue uno de los instrumentos del régimen para propagar el pensamiento ideológico, también es verdad que en comparación con todos los demás instrumentos empleados por el régimen fue el que menos se adscribió al terreno de la propaganda. Otros autores como José María García Escudero hablan de un régimen que más que promover, promocionar o entusiasmar, se movía más por aquello que no permitía que por lo que impulsaba, desde una posición cómoda no se pretendía arengar a las masas sino más bien todo lo contrario, tenerlas adormecidas.

${ }^{24}$ PAZ/ SÁNCHEZ, 1999; "La historia filmada: los noticiarios cinematográficos como fuente histórica. Una propuesta metodológica”, pp.20-21.

${ }^{25}$ SÁNCHEZ BIOSCA/ TRANCHE, 2000: No-Do: El tiempo y la memoria, p. 241.

${ }^{26}$ SÁNCHEZ BIOSCA/TRANCHE, 2000: Op.cit., p. 241. 


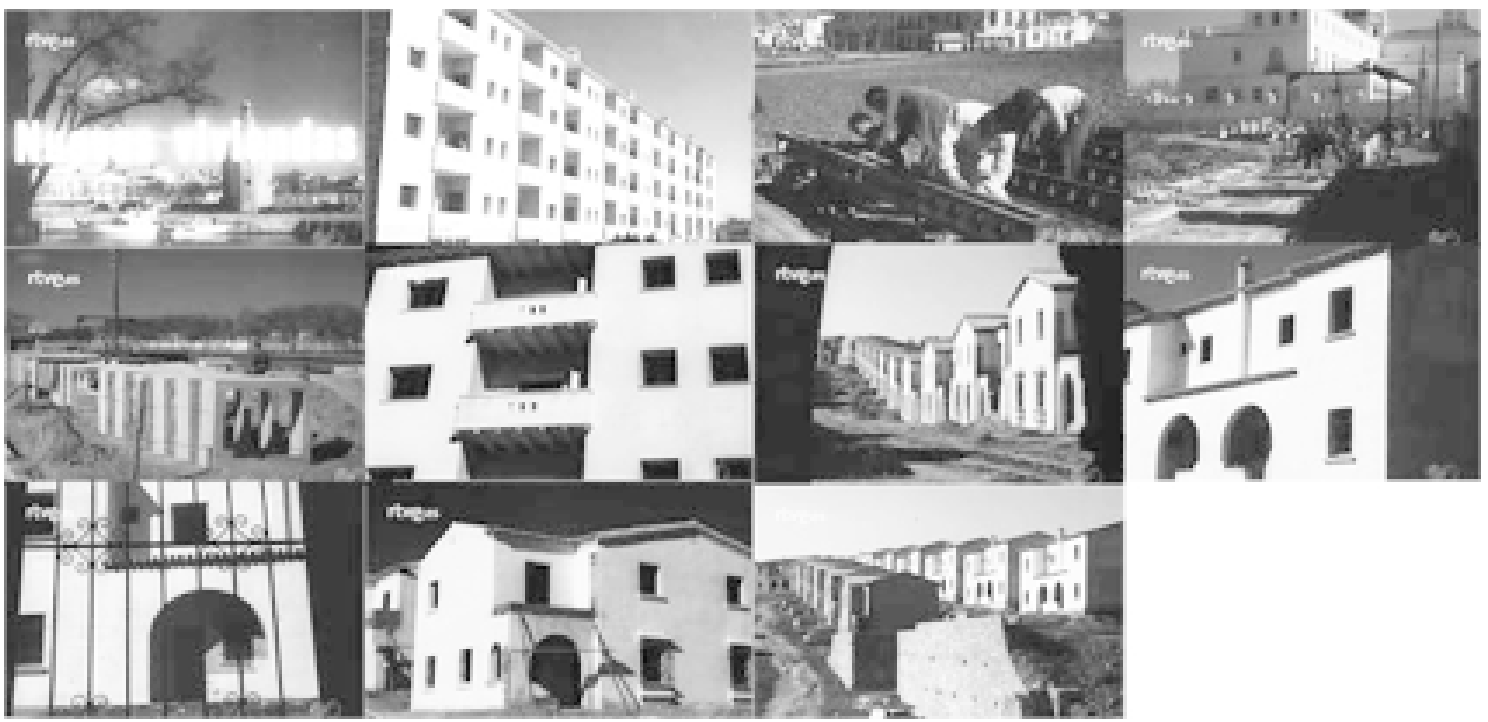

Sec. 4. Secuencia de planos del capítulo. NOT N 532-B marzo 1953. Capturas realizadas en la página del Archivo NO-DO.

Con la muerte de Franco, el NO-DO intentó adaptarse a la nueva realidad, los temas seleccionados y los ámbitos en relación fueron cambiando, pero la llegada de la televisión no permitió que este noticiero se perpetuara en el tiempo. En 1981 dejó de proyectarse, y al año siguiente se le otorgó el rango de Archivo Histórico Nacional, alojándose en los archivos de la Filmoteca Española.

La realidad arquitectónica.

Según la realidad que recoge el NO-DO, se desprenden diferentes clasificaciones de la arquitectura. Autores como Sánchez Biosca, que abordó un estudio de la arquitectura como lugar de la memoria, pero la reconstrucción de una nueva España, no sólo se llevó a cabo restaurando edificios emblemáticos y con poderosa carga simbólica. La recuperación de la realidad española se concretó en a la arquitectura de obra nueva, destacándose aquella que viniera a servir directamente a las necesidades específicas de una sociedad empobrecida por la reciente guerra, como fue la proyección de nuevos edificios destinados al avance de la educación y la sanidad, así como el fomento de la nueva vivienda, destacando en este último caso las acciones del Instituto Nacional de Colonización, la Obra Sindical del Hogar o Regiones Devastadas, entre otros organismos e instituciones. Consideramos que a estas categorias hay que añadir aquellas arquitecturas que las arquitecturas dedicadas al turismo.

La cronología de las imágenes viene establecida por el mismo noticiario, es decir desde enero de 1943, hasta diciembre de 1975, año éste en que se suprimió el carácter obligatorio del NO-DO.

Atendiendo a unas consideraciones previas en las imágenes relacionadas con la nueva arquitectura, fijamos nuestra mirada en el acto inaugural previo a la arquitectura en cuestión, aspecto inseparable de la arquitectura en el NO-DO, ya que no hay arquitectura nueva que no se nos presente en la pantalla sino es con la respectiva comitiva de inauguración acompañada con las correspondientes autoridades políticas y eclesiales, cuestión que refleja la relación indisoluble del Estado con la Iglesia. Así vemos como la arquitectura que se inauguraba, contaba irremediablemente con la bendición de la autoridad eclesial oportuna en la misa de campaña correspondiente. En relación con este rasgo peculiar Ramírez Martínez señaló en su estudio sobre la popularización de la ciencia en el NO-DO, "que pareciera como si tales 


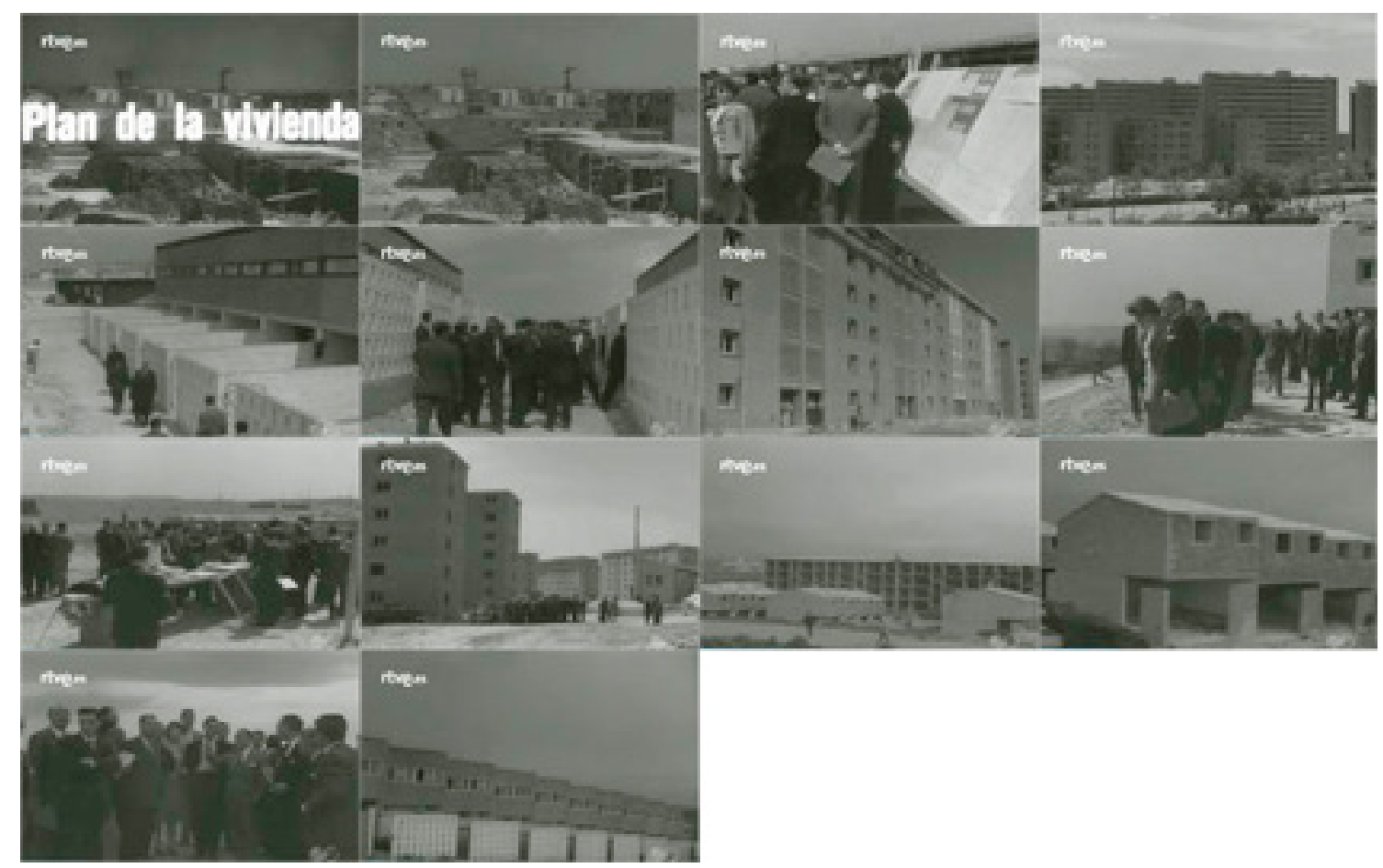

Sec. 5. Secuencia de planos del capítulo. NOT N 802-A mayo 1958. Capturas realizadas en la página del Archivo NO-DO.

logros - arquitectónicos - se debieran a un gratificación divina" ${ }^{27}$. Del mismo modo, en la mayoría de los casos vistos se subraya la arquitectura como símbolo de algo nuevo y grandioso que es posible gracias al caudillo; esta arquitectura está ligada identitariamente más con quien la inaugura que con el arquitecto, el proyecto en sí, o a quien va destinado.

Otro aspecto formal que define las temáticas arquitectónicas, es el título que suele dar paso al fragmento de imágenes que hemos escogido, siendo frecuente encontrar los términos de actualidad nacional, reconstrucción, auxilio social, o nuevas viviendas, precediendo la imagen arquitectónica y en raras ocasiones nos encontramos con la palabra arquitectura. Estas imágenes se ven acompañadas en la mayoría de las ocasiones por una gran masa de gente, en la que no se pueden distinguir individualidades, y donde prima el espíritu festivo y el agradecimiento por una vivienda nueva o colegio nuevo. Lo que es indudable es que el NODO carece de carácter crítico, donde las subjetividades no importan más allá de ser masa. En ocasiones pudiera parecer que lo cotidiano no es de vital importancia, sin embargo consideramos que en este aspecto radica la singularidad del mismo; es en lo más insignificante de la historia donde podemos encontrar el lugar más fecundo para encontrar una nueva lectura que nos haga comprender mejor nuestro pasado.

El impulso de la vivienda.

La vivienda social fue uno de los temas más importantes que tuvo que resolver el régimen. Durante los años que existió el NO-DO se llevaron a cabo diferentes leyes de carácter nacional y reglamentos que impulsaron la creación de nuevas casas, en el documental se puntualizaba mucho la idea de hogar, era una idea muy ligada a modelos tradicionales, es el concepto de hogar que ya apuntó Raimundo Fernández Cuesta. ${ }^{28}$ La mayoría de las cons-

${ }^{27}$ RAMÍREZ MARTÍNEZ, 2008: Op.cit., p. 259.

${ }^{28}$ LÓPEZ DÍAS, 2003: Vivienda Social y Falange: Ideario y construcciones en la década de los 40, p.2. 


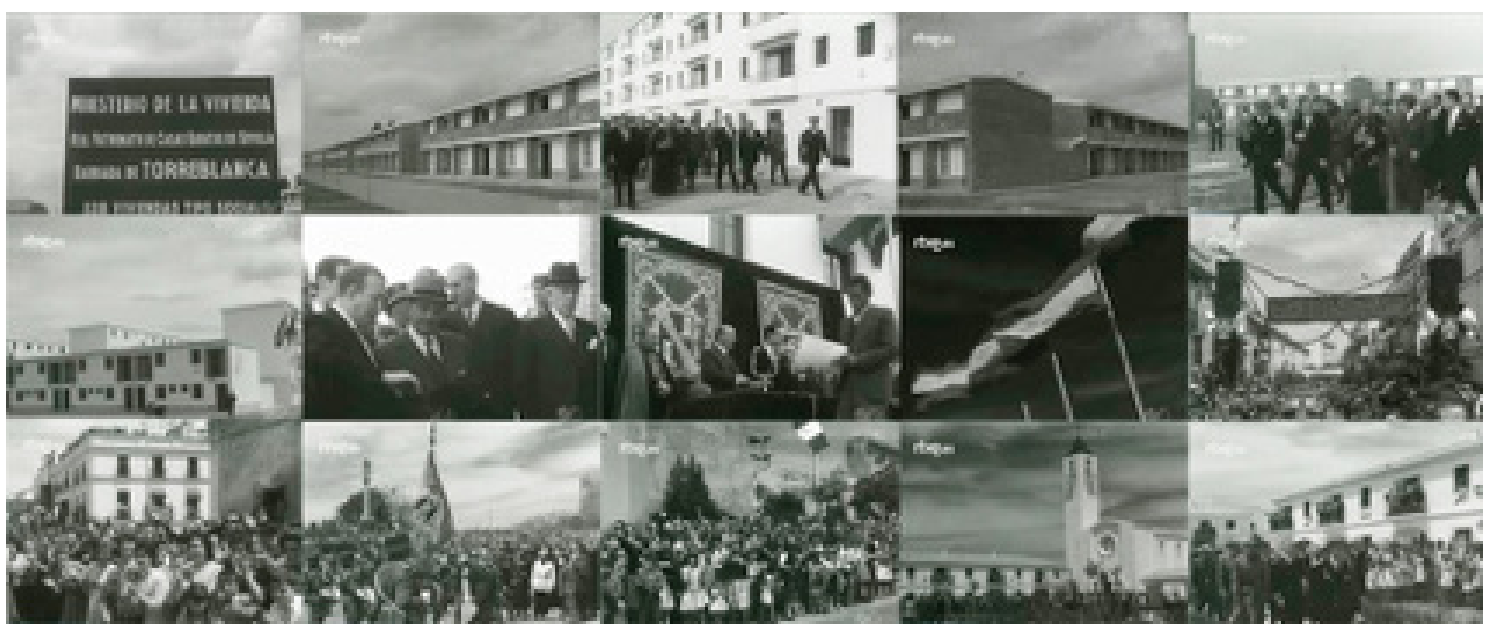

Sec. 6. Secuencia de planos del capítulo. NOT N 957-B mayo 1961. Capturas realizadas en la página del Archivo NO-DO.

trucciones en materia de vivienda fueron impulsadas por el sector público, pues el sector privado fue parco en proveer de unas viviendas que fueran adecuadas y que su coste no fuera excesivo. La reflexión en torno a los conceptos de vivienda protegida y vivienda mínima, enfatizaron aspectos que definían las funcionalidades de cada estancia de una vivienda, o como se distribuían el uso de metros cuadrados por persona, para así dotar a las ciudades de las viviendas necesarias. Es frecuente hallar en las imágenes el antes y el después de una zona que estaba llena de chabolas o de casas en mal estado, y que pasan a ser un nuevo lugar con las edificaciones nuevas y relucientes. Así vemos un conjunto de viviendas protegidas en Torelló (NOT N 16, abril, 1943), entregadas por la Diputación de Barcelona, las cuales contaron con un presupuesto de más de 10.000 .000 de pesetas, y que fueron proyectadas para sustituir las viviendas que se habían perdido a causa de la inundación del rio Ter que había afectado mayoritariamente a jornaleros. Las imágenes (Sec.1.) nos muestran en un primer plano un cartel con las instituciones que impulsan dicha construcción, el Instituto Nacional de Arquitectura y la Diputación de Barcelona; seguidamente el corte de montaje nos enlaza con un cartel del pueblo de Torelló en agradecimiento al caudillo, las imágenes subsiguientes se van hilvanando para mostrar las calles inundadas por una masa que acude complacida al acto de inauguración. Finalmente se nos muestran las hileras de casas en un terreno que se presenta carente de urbanización. El proyecto de dichas casas fue realizado por Antonio Pineda Gualba, ${ }^{29}$ arquitecto de la Delegación Comarcal de Barcelona, Tarragona y Girona. Esta localidad, que fue adoptada por el Caudillo en 1942 debido a la tragedia de las inundaciones ocurridas en $1940,{ }^{30}$ fue de las agraciadas en recibir la reconstrucción anhelada. ${ }^{31}$ Un dato

\footnotetext{
${ }^{29}$ PUJOL BASCO: “Torelló 1931-1975”, pp. 212-214.

${ }^{30}$ Véase:http://www.ajtorello.cat/perfil/recursos/recursos/rp_08_28_conjunt_cases_protecci_oficial_tipus_b1.pdf. El aguacero que afectó a la población la noche del 17 al 18 de octubre de 1940 dejó 62 víctimas mortales, 52 heridos, 118 edificios totalmente destruidos, 132 edificios afectados, 82 industrias afectadas, 114 agricultores afectados, 301 familias afectadas, 1.065 individuos afectados, 2.153 obreros afectados y 81 comerciantes. Las calles más cercanas al río se vieron afectadas, sobre todo las casas construidas con pared de tapia.

31 Véase: http://hemeroteca-paginas.lavanguardia.com/LVE07/HEM/1943/03/26/LVG19430326-003. pdf Los medios periodísticos de la zona se hicieron eco acerca de las nuevas construcciones que iba a ser entregadas a los jornaleros, así el día 25 de marzo de 1943, es cuando registra el periódico La Vanguardia Española, lo que sucedió en la inauguración este medio también relató el carácter festivo que se respiraba en las calles de esta forma: "La población de Torelló se vistió de fiesta, presentando animadísimo aspecto, pues salió a recibir a dichas autoridades y personalidades y sumarse a los citados actos -puede decirse que la totalidad del vecindario.
} 


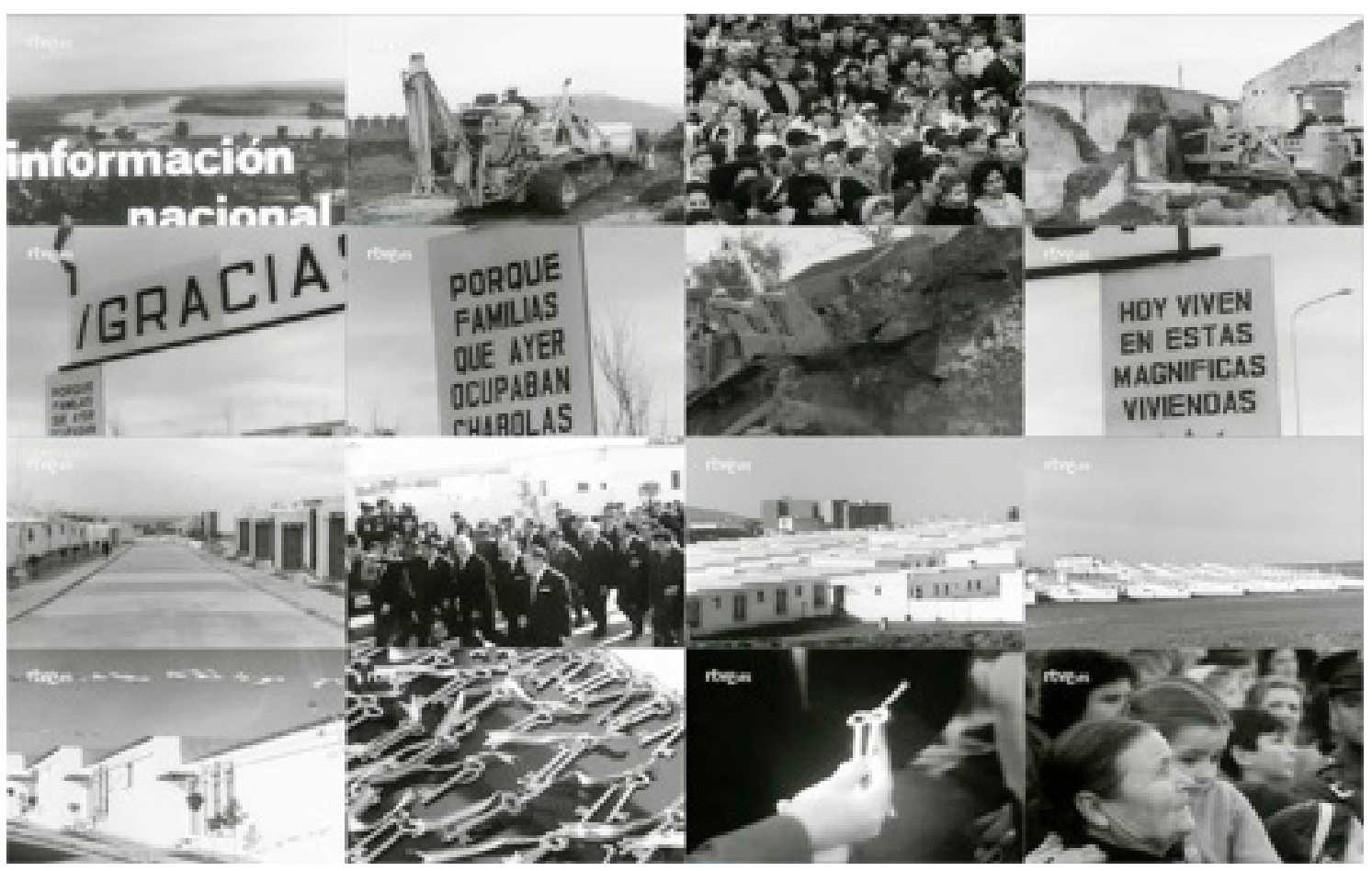

Sec. 7. Secuencia de planos del capítulo. NOT N 1206 -A, febrero, 1966. Capturas realizadas en la página del Archivo NO-DO.

relevante aportado por el periódico La Vanguardia es que en esta inauguración se entregaron cuarenta y cinco casas y no las trescientas que nos relata la voz en off, en esta primera entrega sólo se inauguraron una parte de este nuevo plan de reconstrucción de la localidad de Torelló. ${ }^{32}$ En cuanto a composición arquitectónica se observa un carente uso del ornamento; son viviendas austeras y unifamiliares de doble planta, donde se incluye un pequeño balcón en la segunda planta, y que reflejan todavía esquemas anclados en la tradición aunque de líneas sencillas y austeras.

Regiones Devastadas realizó una extensa labor destinando muchos de los esfuerzos a viviendas, pero este organismo también atendió a necesidades de tipo industrial y empresarial pues también se buscaba la reactivación de la economía española. De este modo hallamos el caso de Lérida (NOT N 66-A, abril, 1944) que contó en los años cuarenta, tanto con viviendas unifamiliares de nueva planta como con nuevas construcciones destinadas a naves industriales. Las imágenes (Sec.2.) que nos muestran las diferentes arquitecturas son precedidas por el intertítulo Reconstrucción. El Director de Regiones Devastadas, José Moreno Torres, hace entrega de unas naves industriales así como del conjunto de viviendas. Las obras se prolongaron a lo largo de tres años y se invirtió en ellas un presupuesto de más de 23.000.000 de pesetas. El pequeño polígono industrial estaba destinado para más de mil quinientos obreros de toda la comarca y las viviendas ubicadas en el pueblo Villanueva de la Barca se proyectaron para cerca de cien familias que habían perdido sus casas; la voz en off nos relata algu-

[...]Casi todas las casas del pueblo ostentaban colgaduras y banderas nacionales y en la entrada del mismo se levantaba un arco de triunfo con la inscripción: "Torelló reconocida al Caudillo" y "Franco, Franco, Franco".

${ }^{32}$ Véase:http:/ / hemeroteca-paginas.lavanguardia.com/LVE07/HEM/1943/03/26/LVG19430326-003. pdf "Que estas cuarenta y cinco viviendas protegidas no se han construido solamente para substituir a las destruidas por la inundación, sino también, como las otras que se construirán, para hacer más confortable la vida de tos productores y mejorar su condición". 


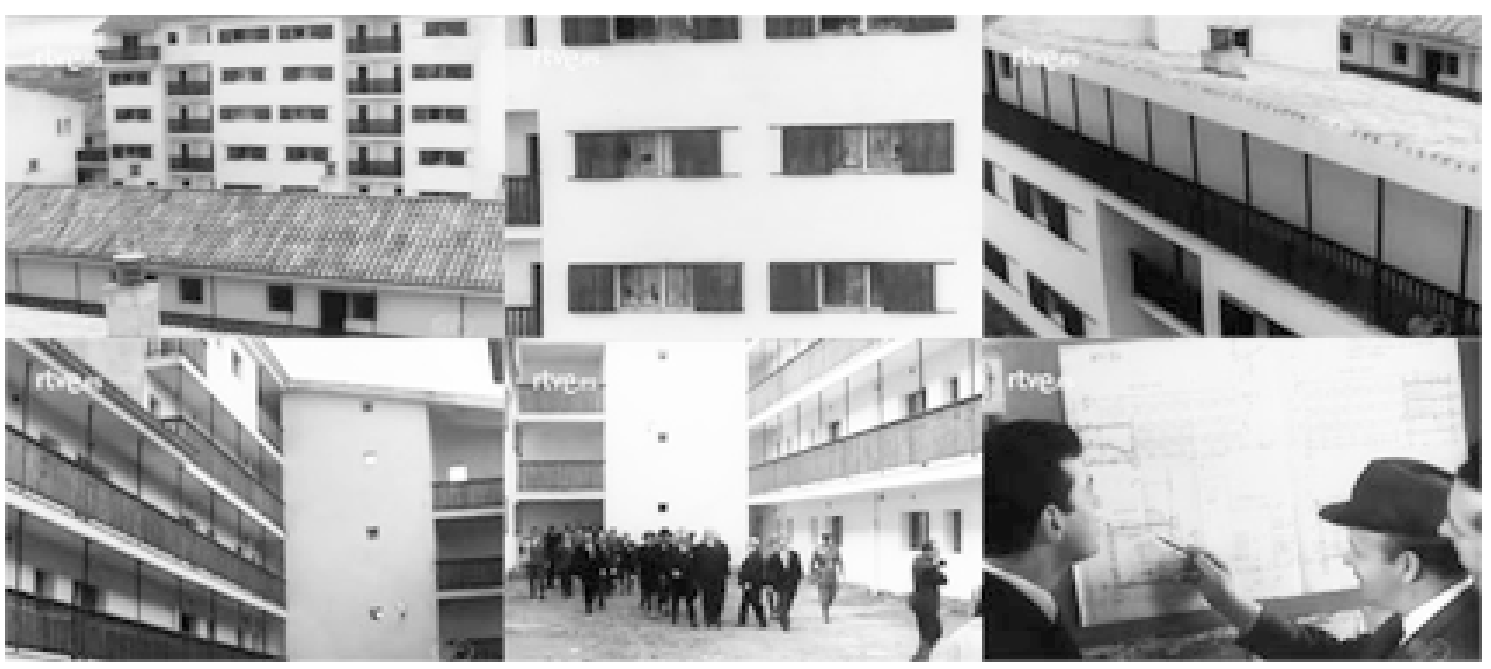

Sec. 8. Secuencia de planos del capítulo. NOT N 1206 -A, febrero, 1966. Capturas realizadas en la página del Archivo NO-DO.

nas características de las casas: ahora son hogares "confortables y alegres". La inauguración repite el esquema institucional con la bendición eclesial. Otras viviendas, que también se han inaugurado entre una multitud que adornaba sus balcones, son las de Mejorada del Campo; el gobernador y jefe provincial del movimiento en Madrid es el que hace entrega de un total de cuarenta y cuatro viviendas, a las que la voz en off reseña como "hogares cómodos y sanos" las cuales forman parte del grupo Ramiro Ledesma Ramos. Las imágenes también reflejan cómo se han pronunciado los pertinentes discursos de las autoridades que están presentes, pues como afirma el locutor se busca reconstruir España: "con afán de superación creciente se realiza en la patria". Observamos que no es una entrega de llaves, o entrega de escrituras; las casas ya están habitadas, la inauguración se ha celebrado con posterioridad, pues se aprecian rasgos que nos hablan de ello como diferentes enseres expuestos en el exterior, el conjunto de casas es nuevo, de ahí que todavía no se aprecien en las imágenes las infraestructuras urbanísticas necesarias, como es el acerado o iluminación de las calles.

Otro epígrafe que encontramos relacionado con las nuevas viviendas es el de Actualidad Española, así aparece enmarcado este capítulo de NO-DO (NOT N 336-A, junio 1949),

que en esta ocasión carece de audio que nos pueda dar alguna información añadida. En este apartado (Sec.3.) se hace entrega de nuevas viviendas, con el acostumbrado acto multitudinario de inauguración. La tipología de casas que vemos aquí, corresponde a una vivienda unifamiliar de una sola planta con un pequeño porche delantero, y sin aportaciones novedosas desde el punto de vista estilístico, muy anclado en los regionalismos de corte simplista; todavía aquí no se recogen algunos de los avances que ya estaban dando en España. La información extra la conocemos gracias al programa de mano, que nos dice que estas viviendas se entregan con motivo de la feria de Córdoba, es el único dato que conocemos de su localización.

Las barriadas de casas económicas fueron otro hábito común de estos años; un buen ejemplo de ello se desarrolló en Sevilla, concretamente en el barrio de Nervión (NOT N 532-B, mazo, 1953). En este capítulo se hace entrega (Sec.4.) de viviendas construidas en cadena, lo que ha permitido abaratar los costos, el tiempo y la mano de obra. La novedad que nos cuenta la voz en off, es que el primer bloque se construyó en un periodo máximo de 50 días y en total comprende 40 viviendas, la capacidad de los edificios ha permitido que se den dos tipologías. El coste total del primer bloque ha sido de 1.750 .000 pesetas, posteriormente se terminará el segundo bloque, y está previsto construir más bloques con esta metodología. También en este capítulo y en Sevilla, se han construido un grupo de quinientas casas, esta labor ha sido fomentada por la Obra Sindical del Hogar, como entidad colaboradora del 


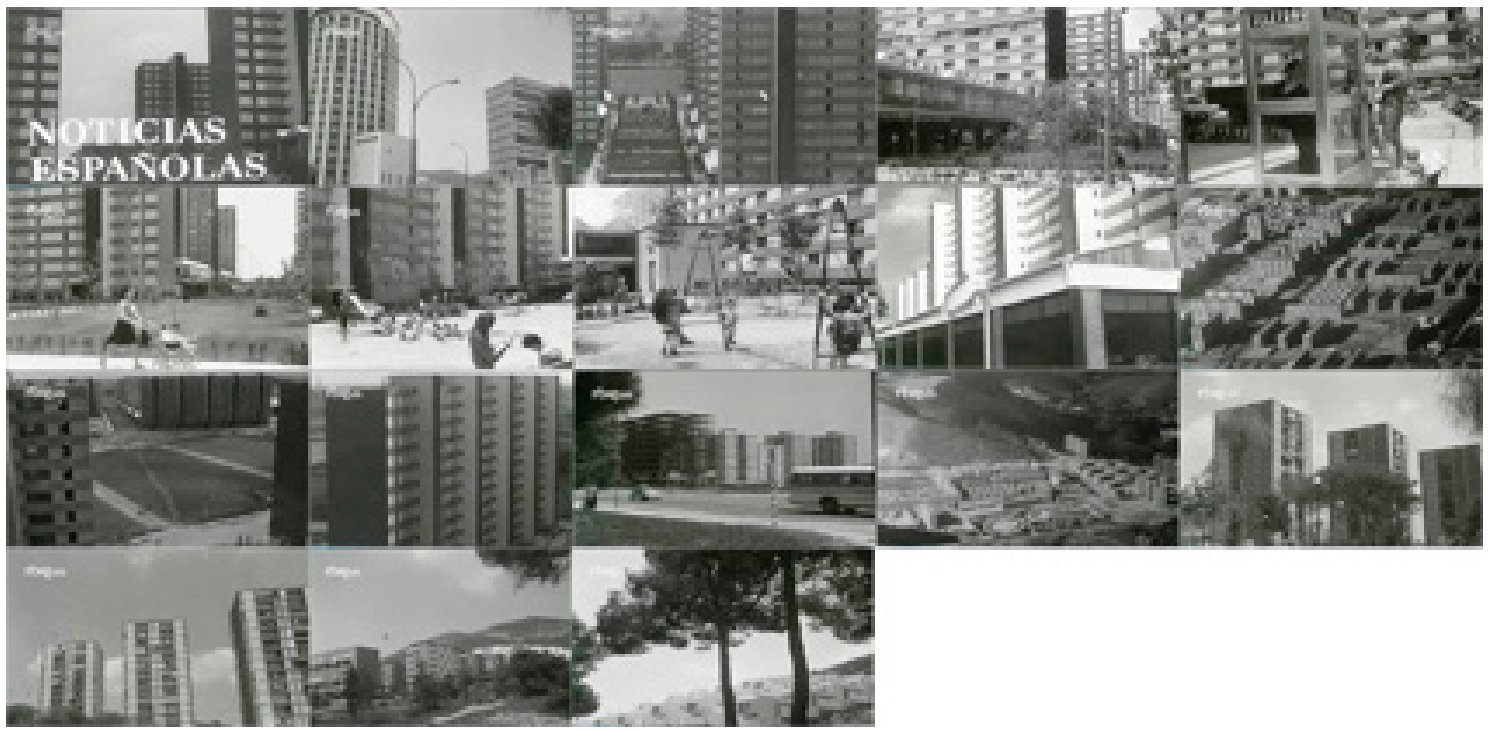

Sec. 9. Secuencia de planos del capítulo. NOT N 1337 -A, agosto, 1968. Capturas realizadas en la página del Archivo NO-DO

Instituto Nacional. Este grupo de casas recibe el nombre de Grupo Fernando Coca, y cuenta con más de dieciséis calles, cuarenta y cuatro de estas viviendas poseen el espacio para un local comercial, siendo su amortización mensual variable, de 85 a 341 pesetas, ascendiendo el presupuesto total de la obra a más de 36.000 .000 de pesetas. Las casas más económicas tienen una prima de construcción, esto permitió apaciguar el problema en materia de vivienda que tenía la ciudad de Sevilla.

Los planes de vivienda que se pusieron en marcha en capitales como Madrid y Barcelona estaban destinados a suplir un problema social en este aspecto; en las ciudades con más población, el problema era mayor. De este modo vemos el ejemplo del Plan de Vivienda de Madrid (NOT N 802-A, mayo, 1958) llevado a cabo a finales de los años cincuenta. En esta ocasión observamos como un grupo de periodistas visita una de las zonas donde se encuentran una buena parte de estas nuevas construcciones (Sec.5.), algunas de ellas próximas a ser concluidas. Las secuencia de imágenes nos muestra una intensa actividad arquitectónica, a los periodistas se les ha facilitado el acceso a diferentes planos de alzado, sección y planta. En esta zona se albergan casi la mitad de este plan de urgencia social, que se ha establecido en Madrid, con este plan se dotará a la ciudad de un total de 60.000 viviendas. Esta inversión de presupuesto y suelo ha supuesto también una adecuación de infraestructuras en materia de urbanismo y de comunicación viaria, para lo cual se está construyó una autopista de circunvalación, pues la zona nueva que surgió gracias a este plan, supuso la construcción de unos siete polígonos urbanos.

Como vemos, la tendencia arquitectónica en estos años estaba vinculada no solamente a edificios sino a generar zonas nuevas urbanizadas, ya fueran grandes barrios, polígonos o pequeños poblados que impulsaba el Instituto Nacional de Colonización. En varios pueblos de Sevilla podemos observar esta variedad (Sec.6.), así vemos una nueva barriada en Torreblanca de los Caños, y otra en San Juan de Aznalfarache (ambas en Sevilla) también encontramos un ejemplo de la labor del Instituto Nacional de Colonización en Jerez de la Frontera. (NOT N 957-B, mayo, 1961). La primera de las barriadas mencionadas es inaugurada por Franco, en total se han construido 528 viviendas de tipo social, y con capacidad para 1608 familias. Esta nueva barriada viene a suplir las malas condiciones en las que se encontraban anteriormente estas viviendas, pues esta zona se había convertido en un suburbio, y ahora según el narrador se le está otorgando el regalo de tener "hogares limpios y decorosos". En otra barriada de Sevilla, en San Juan de Aznalfarache, observamos un modelo de vivienda cercano a presupues- 


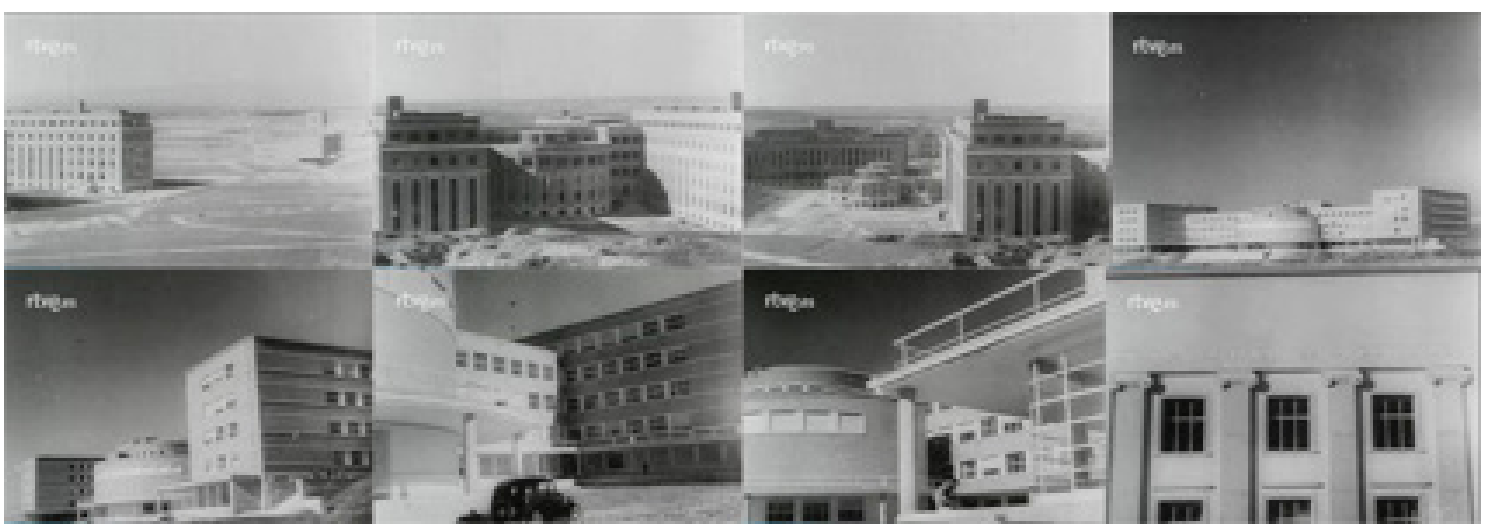

Sec. 10. Secuencia de planos del capítulo. NOT N 8, febrero, 1943. Capturas realizadas en la página del Archivo NO-DO.

tos más modernos, plantea nuevas soluciones arquitectónicas, así por ejemplo observamos una techumbre plana que se diferencia del ejemplo anterior siendo este primero un tejado a dos aguas. Las imágenes nos muestran el acostumbrado acto inaugurativo donde el caudillo hace entrega de los títulos y las llaves a cinco de las familias ubicadas primeramente en estas nuevas viviendas, lo que ha permitido "redimirlas de su penosa situación", coletilla introducida de nuevo por el locutor. Finalmente, encontramos en este capítulo una muestra de la colonización con nuevos poblados impulsados por el INC. Por último en Jerez, encontramos el pueblo Guadalcacín del Caudillo, en el que se han levantado 109 viviendas para colonos que corresponden el lote familiar y 59 viviendas para el lote complementario.

Con el epígrafe "Información Nacional", (NOT N 1206-A, 1966) encontramos un interesante ejemplo de la arquitectura promovida por el régimen en Badajoz, donde no sólo se muestra lo nuevo e inaugurado, sino lo que fue anteriormente; es una muestra comparativa que nos permite ver cómo vivían muchos españoles entre paredones. Este es uno de los ejemplos más interesantes desde el punto de vista de la construcción de la imagen (Sec.7), así como por la sustentación de la idea de que gracias al avance que permite el caudillo, cada día hay más hogares en España. De hecho la locución nos recuerda que las imágenes que vemos es algo habitual en muchas zonas de la nación española. Después del fundido a negro arranca el siguiente fragmento guiado por unas palabras pronunciadas por el narrador que subraya que "es un hecho corriente que se viene repitiendo desde algunos años en la España del momento, y es nada más y nada menos que la obra portentosa del caudillo, que suministra de dignas viviendas a todo español necesitado". Es destacable aquí el montaje realizado, donde lo que no se dice con palabras se pronuncia con imágenes. Se observa así la alternancia de planos, donde vemos multitudes aplaudiendo en la inauguración y entrega de llaves de las nuevas viviendas, así como el derribo de lo que fue su hogar, hechos con distancia temporal entre uno y otro, pero que aquí por medio del plano contraplano se nos muestra como una secuencia que altera el tiempo y el espacio; esto ocurre gracias a que no se nos muestran planos generales del contexto, ni del derribo ni de la inauguración de las nuevas casas, son planos recortados al detalle. Aún más interesante resultan en este caso los textos que nos señala intencionalmente la cámara, de nuevo por medio del corte de montaje. Así nos muestra un primer plano de un cartel que recoge las palabras: "porque familias que ayer ocupaban chabolas", para pasar a un segundo plano por medio del corte, que da lugar de nuevo a la imagen del derribo, y otro corte que nos lleva al segundo cartel: "hoy viven en estas magníficas viviendas". En estos planos, ambos textos se nos presentan separados, pero son parte de un mismo arco instalado para la inauguración. Por último, otro corte nos muestra un plano general de la calle del nuevo barrio, que se nos muestra vacía y sin los nuevos vecinos, en la que destacan las evidencias de las obras de urbanización pertinentes, incluyendo incluso pequeños árboles en el acerado. A las alturas de año que estamos, 1966, 


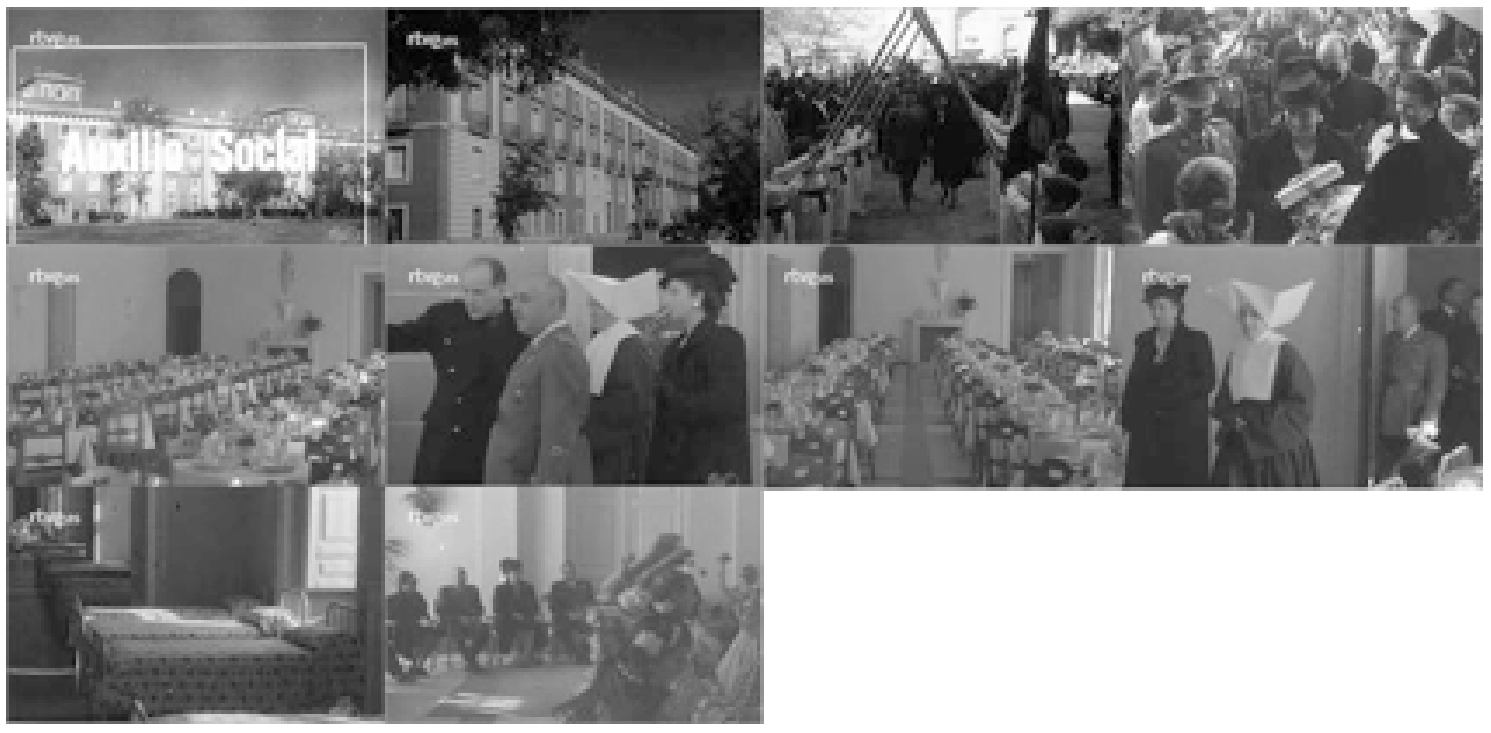

Sec. 11. Secuencia de planos del capítulo. NOT N 150-A, noviembre, 1945. Capturas realizadas en la página del Archivo NO-DO

estas pequeñas diferencias de urbanización nos muestran como se ha ido avanzando en las gestiones de conjuntos de casas, que antes se entregaban dispuestas en antiguos solares baldíos de toda infraestructura. Otra imagen (Sec.8.) que nos devuelve la cámara en este capítulo es una nueva barriada en Mérida, que ha surgido al "calor del desarrollo de España", como afirma la voz del narrador. Nuevas construcciones se han levantado en Cardenal de la Sierra, que consisten en bloques de viviendas en altura, en los que destacan las persianas correderas horizontales, que nos recuerdan a la arquitectura que ya se promoviera en Alemania con la Bauhauss, aunque aquí la techumbre se sigue representando a dos aguas. En estos nuevos barrios se aprecian las disposiciones ortogonales de calles y casas, esquemas rectilíneos y exentos de ornamento, que de nuevo evidencian la penetración de los principios de la arquitectura del movimiento moderno que tanto proclamó Le Corbusier a principios de siglo. Lo más destacable aquí a nuestro modo de ver es que ya se está separando la idea de hogar asimilada únicamente a una vivienda de una sola planta y de carácter unifamiliar.

Continuando con las tendencias arquitectónicas que paliaron los problemas de habitabilidad de la España de los sesenta, vemos la construcción de grandes polígonos populares de vivienda, que permitían en menor desarrollo de terreno y así albergar en vertical innumerables viviendas. Uno de estos casos lo vemos desarrollado en Barcelona (NOT N 1337-A, agosto, 1968). En este capítulo observamos entre otras cuestiones como el encabezado del epígrafe ha cambiado a ser Noticias Españolas. Las imágenes (Sec.9.) nos muestran diversos ejemplos de polígonos que se han ido construyendo en el extrarradio de la ciudad condal. El primer caso se desarrolla en la zona conocida como el Biche. Gracias al Patronato Municipal de Viviendas, se han construido en esta zona más de 2.000 viviendas desde la fundación del polígono, las cuales han llegado a ser ocupadas por 12.000 personas aproximadamente. El terreno ocupado es de 70 hectáreas, lo que permitirá que en este polígono lleguen a vivir 70.000 vecinos. Se destacan además en las imágenes los servicios con los que cuenta este polígono, como una guardería infantil o una amplia zona de recreo. Otro polígono de carácter residencial y para trabajadores, ha sido levantado en la zona del Besós, 4863 viviendas y 261 locales comerciales. Diferentes tomas aéreas de lo que parecen ser fotografías nos muestran los diferentes conjuntos de polígonos, donde se puede observar la gran implicación de las obras desarrolladas. La zona de Montbau cuenta también con otro polígono de la misma tipología, en donde se han construido más de 1.700 viviendas que cuenta con un número 


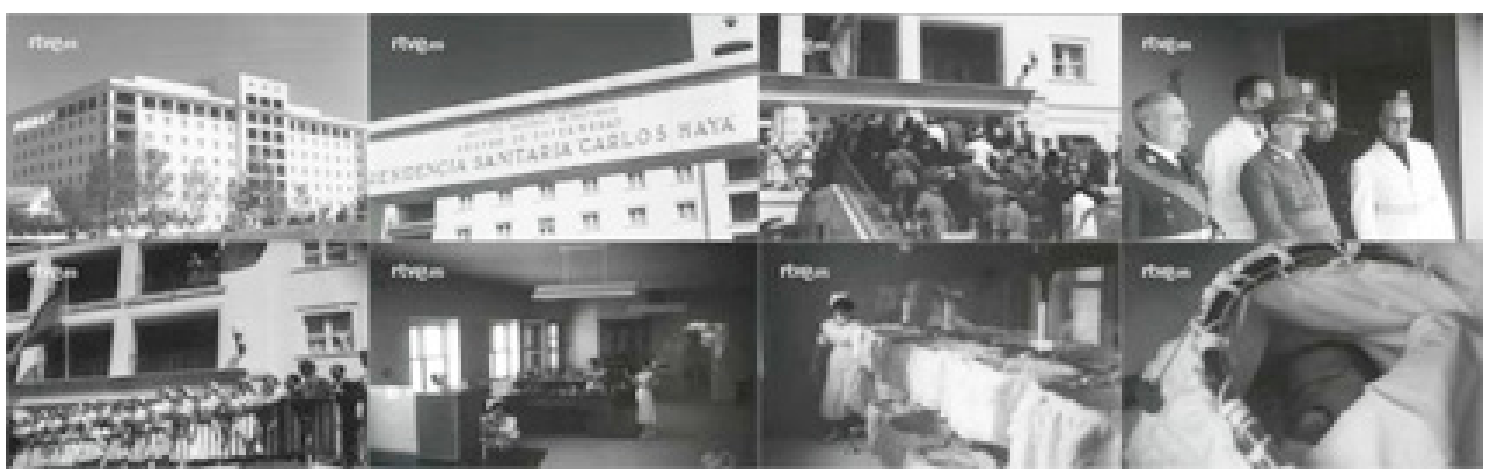

Sec. 12. Secuencia de planos del capítulo. NOT N 696-A, mayo, 1956. Capturas realizadas en la página del Archivo NO-DO

aproximado de 90 locales comerciales, e incluso está dentro del proyecto la construcción de instalaciones deportivas, y de carácter social y cultural. Según la conclusión del narrador, al ritmo acelerado que se está construyendo pronto "el problema de la vivienda dejara de serlo en breve", subrayando que estas obras acometidas tienen una "profunda repercusión humana y social". El diseño y el estilo arquitectónico de estas viviendas nos muestra aún más la permeabilidad del influjo extranjero que en arquitectura se da en estos años, aquí se evidencian conceptos de servicios que viene aparejados a las viviendas, lo que supone un avance sustancial. La solución arquitectónica empleada en estos polígonos, es depurada estilísticamente y refleja una tendencia de construcción que fue la mejor opción para resolver el problema acuciante de las viviendas.

\section{Arquitectura de servicios: Sanidad y Educación.}

La arquitectura dedicada a la Sanidad que es recogida en el NO-DO resalta los nuevos avances en medicina, del mismo modo que muestra las consideraciones de nuevas funcionalidades en los usos del espacio sanitario, buscando el mayor confort para el paciente. Así mismo se refleja en este noticiario aquella arquitectura que impulsa los valores de educación promulgados por el régimen; por ello es usual en las imágenes comprobar como laboratorios y otras aulas técnicas están dotadas con lo último en cuanto a educación técnica se refiere. En este sentido los ejemplos que hoy podemos visionar en el Archivo de la Filmoteca Española, encontramos el caso de la Ciudad Universitaria de Madrid (NOT N 8, 22 febrero, 1943). Esta edificación es relevante no sólo porque es un edificio con proyección de futuro, pues de este edificio saldrán un gran número de universitarios preparados como nueva generación, sino porque el lugar donde se ubican ahora las nuevas construcciones fue bastión de la fortaleza nacional, así nos lo hace saber la voz narrativa que nos muestra unas imágenes (Sec. 10.) con una perspectiva general de este conjunto, para después pasar a imágenes con más cercanía, las cuales están acompañadas de una música triunfalista y alegre que nos habla de "ilustre abolengo de este escenario", como así lo afirma la voz en off. Se observa un conjunto de edificios con una composición cuidada, muy geométrica y exenta de ornamento; para finalizar la secuencia de imágenes, la pantalla nos devuelve una única fachada de todas las facultades que hay en este conjunto universitario, aspecto que podría no ser aleatorio, se nos muestra la fachada de la Facultad de Arquitectura, que está ornamentada con unas sutiles pilastras con capitel jónico, cuestión que nos permite hacer una lectura sobre la identidad e importancia del papel fundamental de la arquitectura como disciplina y como artífice de la Ciudad Universitaria de Madrid.

Otro epígrafe con el cual solemos encontrar nuevas construcciones, es el referido Auxilio Social, así vemos la inauguración de un Hogar Escuela en Boadilla del Monte, (NOT N 150A, noviembre, 1945). En esta ocasión es el Jefe del Estado quien lo inaugura; como novedad observamos que aquí la cámara tiene acceso al interior, lo que nos muestra las diferentes ha- 


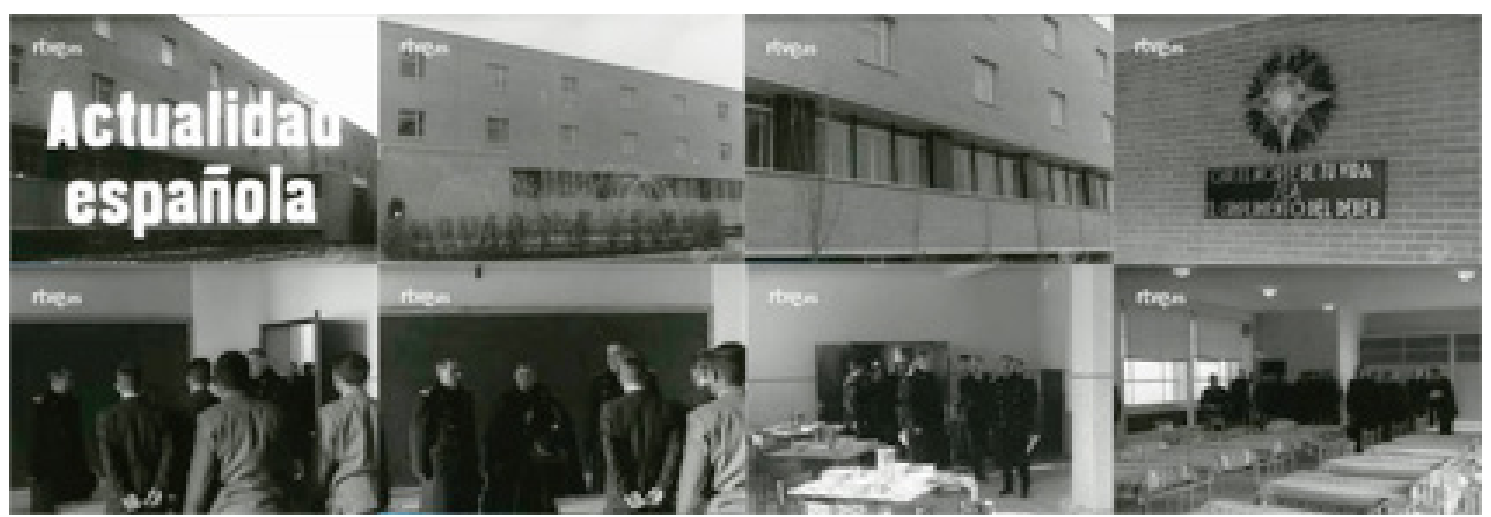

Sec. 13. Secuencia de planos del capítulo. NOT N 938-A, diciembre, 1960. Capturas realizadas en la página del Archivo NO-DO

bitaciones y otras instalaciones. A modo de colofón se desarrollan unas escenas de folclore, pues la secuencia de imágenes (Sec.11.) se cierra busca entre otras cuestiones reafirmar la identidad española. La arquitectura que observamos en los exteriores está muy ligada a un tiempo anterior, podríamos decir que resalta un cierto estilo anclado en modelos del pasado.

En la ciudad de Palencia acudimos a otro acto inaugurativo, donde observamos la Residencia del seguro de enfermedad, la cual ostenta el nombre de Lorenzo Ramírez y el Colegio de Huérfanos de ferroviarios; A ambos actos acude el Jefe del Estado junto a su esposa, también le acompañan otras autoridades. En la primera de las inauguraciones se aprecia una gran masa de gente que lo recibe con aplausos; es curioso como el sonido de los aplausos se prolonga durante bastante tiempo mientras trascurren las imágenes, para después ser cortado de manera abrupta y sin correspondencia con el final de un aplauso natural, son los aplausos del fervor al caudillo. Esta residencia cuenta con instalaciones para atender a un total de trescientos pacientes, ocupa una superficie de más de $7.000 \mathrm{~m} 2$, y se distribuye en seis plantas dotadas con los últimos avances en medicina. Por otra parte el colegio de huérfanos está acondicionado para albergar a quinientas niñas, las cuales están a cargo de las monjas salesianas; se ha llevado a cabo la pertinente ceremonia de bendición para finalizar con unas demostraciones de baile clásico y baile regional. Apenas la cámara se posa en las particularidades arquitectónicas, de nuevo se confirma que la arquitectura ha sido la gran sierva del régimen.

En materia sanitaria se nos muestran grandes avances, en uno de los casos analizados observamos como Franco (NOT N 696-A, mayo, 1956) inaugura la residencia sanitaria de la seguridad social "Carlos Haya” de Málaga (Sec. 12.), junto con el pabellón de Poliomielitis o la casa cuna, todos estos edificios están dotados de los últimos avances tecnológicos. Así la voz del narrador ensalza la labor que se está desarrollando en España, constituyendo "estos ejemplos con notorios avances así como modelo y ejemplo dentro de este género". Dentro del epígrafe actualidad española, también encontramos otro capítulo de NO-DO, en el que se nos muestra la inauguración de una escuela para hijos y huérfanos de suboficiales, es la escuela de Nuestra Señora del Carmen ubicada en la ciudad lineal de Madrid (NOT N, 938B, diciembre, 1960); está destinada a huérfanos e hijos de

Suboficiales de la Armada, construida en un solar de más $3.900 \mathrm{~m}^{2}$, la cual ha sido inaugurada por el Ministro de la Marina (Sec.13.), el Almirante Amarzuza, y otras autoridades. Esta escuela cuenta con 138 plazas en régimen de internado, y en ella se impartirá la enseñanza primaria y el bachillerato, para finalmente poder realizar los estudios en la marina mercante.

Finalmente el último ejemplo escogido es aquel que nos muestra los avances en la ciudad sanitaria de Madrid que lleva por nombre Francisco Franco (NOT N 1252-C, enero, 1967). Ahora se inaugura uno de los edificios que es parte de este gran complejo sanitario, una clínica psiquiátrica con capacidad para 140 camas y dotada de los últimos avances de esta especialidad médica. La cámara (Sec.14.) también nos muestra cómo avanzan el resto de pabellones y edificios que aglutinaran esta ciudad sanitaria, que contará con hospital, pabellón de Onco- 


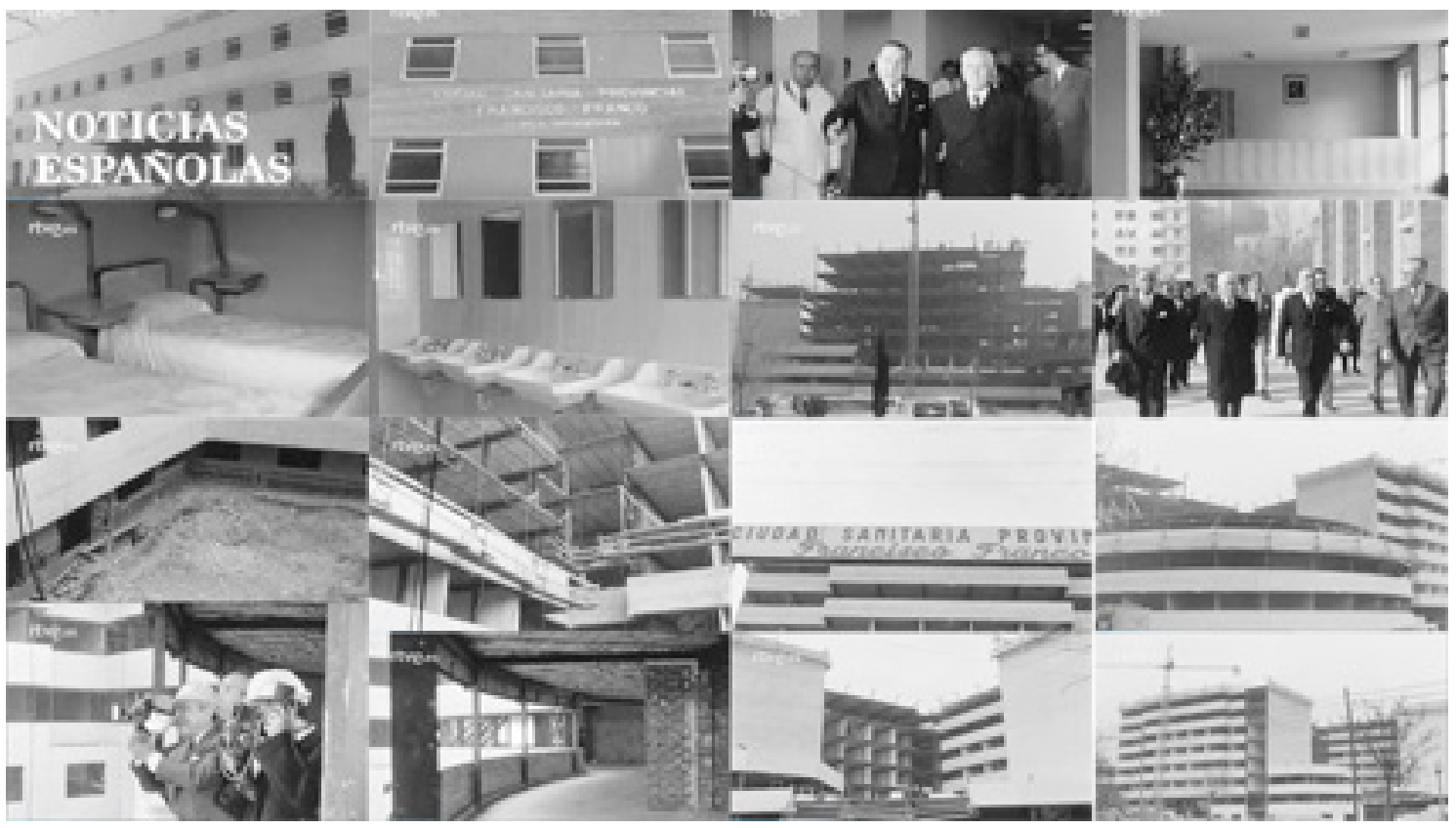

Sec. 14. Secuencia de planos del capítulo. NOT N 1252C, enero, 1967. Capturas realizadas en la página del Archivo NO-DO

logía, parque móvil, clínica médico-quirúrgica e imprenta, y todo ello bajo la advocación de San Juan de Dios. En este complejo sanitario se aprecian formas de composición muy ligadas a la arquitectura del movimiento moderno; uno de los edificios que vemos de planta circular supone planteamientos novedosos desde el punto de vista constructivo y espacial, y parece demostrar que la arquitectura española está lista para enfrentarse a nuevos retos.

Arquitectura ligada a la funcionalidad del turismo.

Franco empleó todos sus esfuerzos para hacer propaganda del régimen, y en concreto en el turismo encontró un aliado de gran estima. La palabra turismo sobreabunda en los capítulos del NO-DO a partir de los años cincuenta. Desde el régimen se quería dotar de una nueva imagen para proyectarla hacia el exterior, y se buscaba que España fuera uno de los destinos escogidos por los extranjeros, así como por los nacionales. ${ }^{33}$

Observamos en la búsqueda realizada en NO-DO que la inauguración de Paradores Nacionales aparece con más frecuencia a partir de la mitad de los años cincuenta. Esto podría estar relacionado con la apertura económica que se está comenzando a experimentar, pues aunque en los primeros años si hubo alguna actividad en el sector turístico, lo cierto es que la urgencia que planteaba el problema de vivienda no permitió muchos avances en este sector. Así hemos querido destacar aquellos paradores que tanto por su tratamiento en el Noticiero que nos ocupa, como por su representación arquitectónica, suponen un ejemplo para nuestro estudio.

Aunque es evidente que en estos años comienzan las construcciones hoteleras, hemos queridos posar nuestra mirada en el papel que cumplieron los paradores, como construcción turística impulsada por el régimen franquista.

Así observamos el caso del Parador Nacional de Teruel (NOT N 714-B, 1956), que es un fiel reflejo, según el narrador de la "tendencia arquitectónica actual en contraste con los

${ }^{33}$ CORREYERO RUIZ, 2003: La propaganda turística y la política turística española durante el franquismo cuando el turismo aún no era de masas Universidad Católica San Antonio, pp.2-3. 


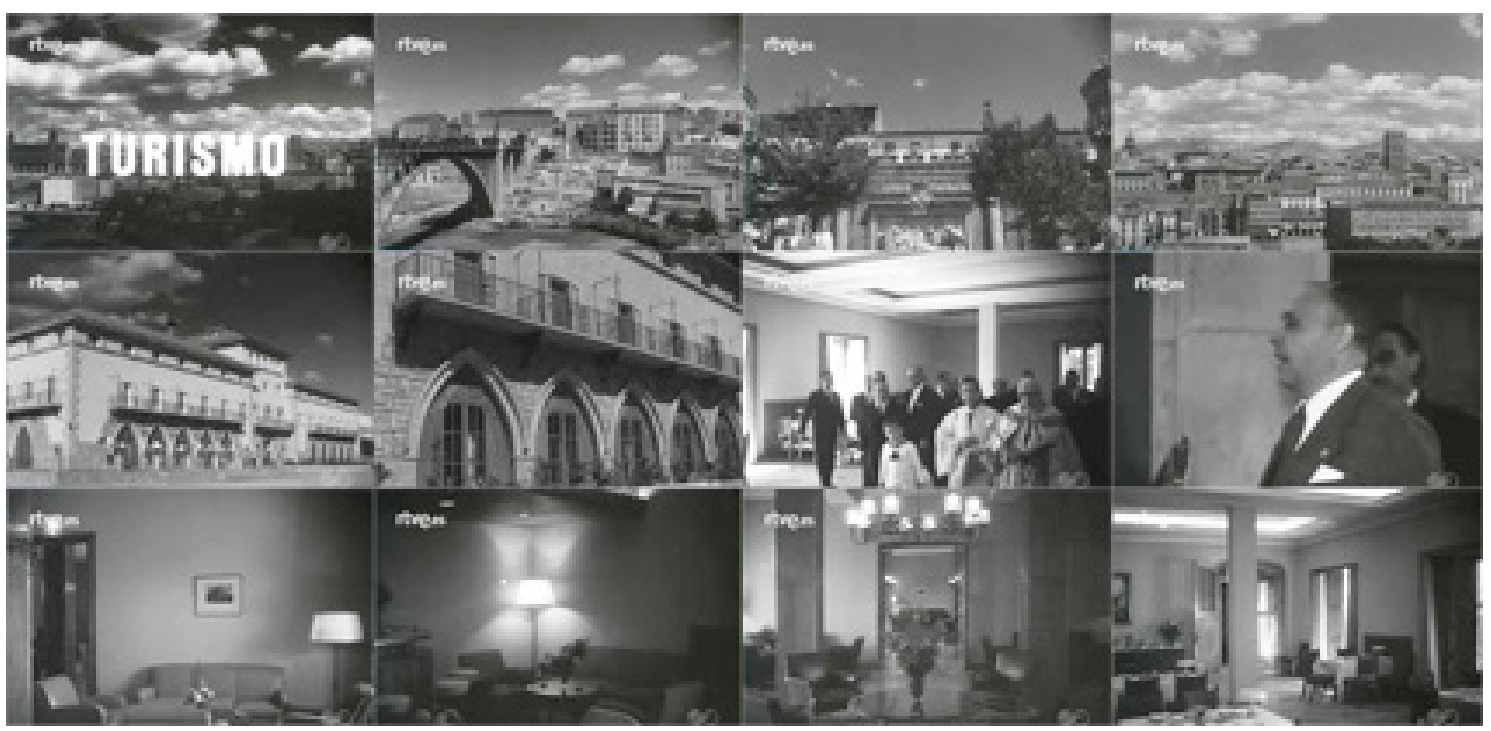

Sec. 15. Secuencia de planos del capítulo. NOT N 714-B, 1956. Capturas realizadas en la página del Archivo NO-DO

edificios históricos que recogen el legado del pasado". Así observamos un edificio (Sec. 15.) que pretende atraer el turismo hacia el interior, y del que se desprenden unas nuevas formas estilísticas, y que el noticiario considera como una de las mejores obras que se han realizado en ese momento en España; es destacable que es un alojamiento que ha pretendido prescindir de lujos superfluos, y que busca más bien la comodidad, sencillez y funcionalidad.

En la ciudad de Córdoba encontramos otro ejemplo de Parador, es la Arruzafa, (NOT N 934-C, noviembre, 1960). En la secuencia de imágenes (Sec.16.) seleccionadas encontramos como Franco es quien inaugura estas nuevas instalaciones en compañía de su esposa, diferentes ministros y personalidades. Este parador fue mandado construir por la Dirección General de Turismo, y está provisto de cuatro plantas con 56 habitaciones dobles, también está dotado de los últimos adelantos, así como de espacios diáfanos y confortables, que disfrutan de la ubicación del parador en un paisaje excepcional, la sierra cordobesa, como afirma el narrador "el Parador de la Arruzafa se iguala en gusto y comodidad de los mejores establecimientos extranjeros".

Otro ejemplo de Parador es el de Mojácar (NOT N 1210-B, 1966), parador número 50 y que está situado junto al mar (Sec.17.), constituyendo uno de los ejemplos más notables en

cuanto a modernidad se refiere, y en el que observamos un incipiente acercamiento hacia la arquitectura moderna, con balcones voladizos que nos recuerda a diferentes soluciones arquitectónicas de la Bauhaus o de Rafael de la Hoz; se aprecia así que la techumbre se ha resuelto con esquema plano, dejando a un lado las dos aguas. Observamos también ventanales corridos, y el enfoscado es liso o de ladrillo visto sin ornamentación alguna y en el que abunda el color blanco y las líneas rectas. El edificio principal está elevado sobre pilares vistos, creando una galería inferior que rodea una piscina, aspecto que nos recuerda mucho a la arquitectura Corbusiana. En el interior se observan espacios diáfanos, con una escultural chimenea exenta en el centro del recibidor, predominan los acabados modernos.

Con el ejemplo del Parador Nacional de Nerja (NOT N 1211-B, 1966) se quiere destacar lo acometido hasta el momento, en lo que se refiere a la ampliación de instalaciones turísticas en España (Sec.18.), que viene a suplir en muchas ocasiones la iniciativa privada; en este parador llama nuestra atención la instalación de una torre que alberga el ascensor diseñado para facilitar el acceso a la playa, y así salvar el desnivel entre la tierra firme y la playa. 


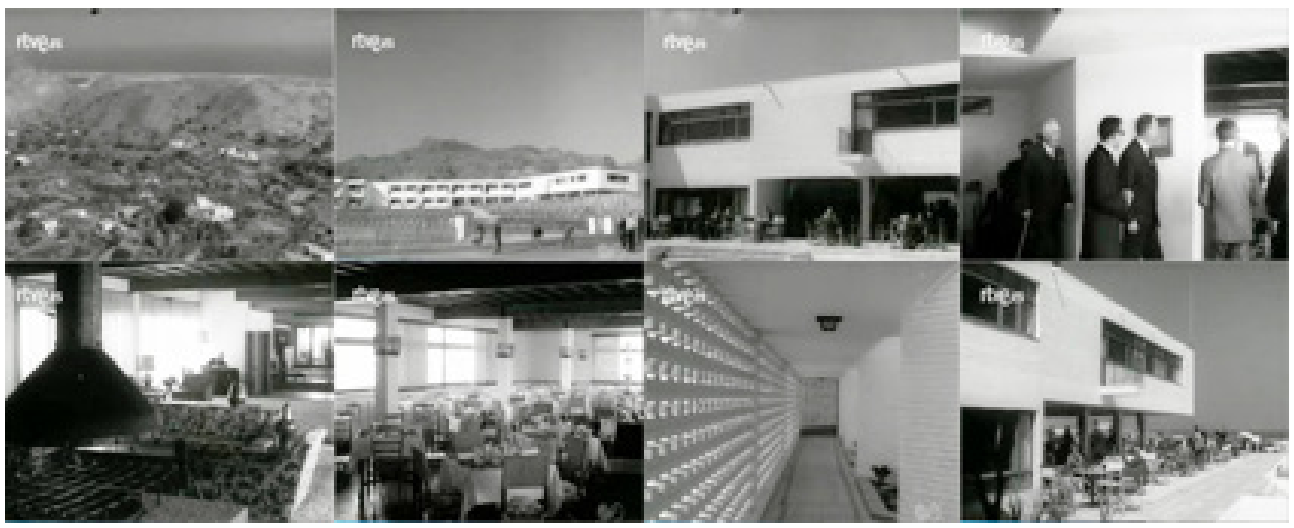

Sec. 16. Secuencia de planos del capítulo. NOT N 934-C, 1960. Capturas realizadas en la página del Archivo NO-DO

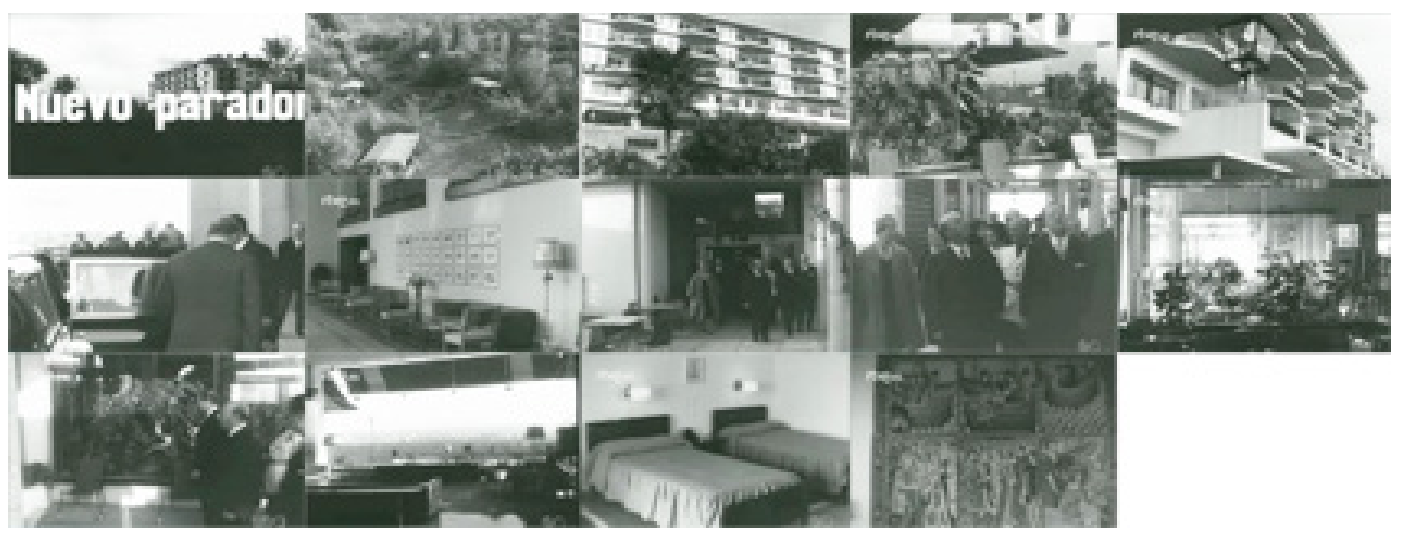

Sec. 17. Secuencia de planos del capítulo. NOT N 1210B, 1966. Capturas realizadas en la página del Archivo NO-DO

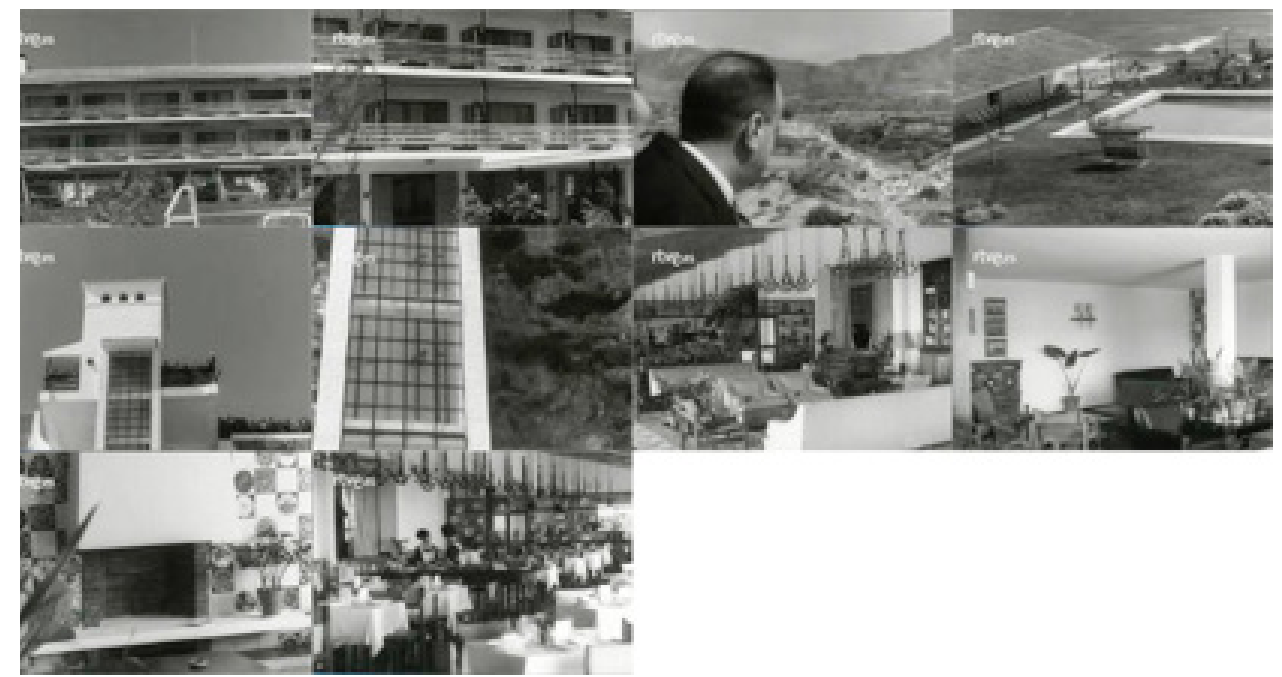

Sec. 18. Secuencia de planos del capítulo. NOT N 1211B,, 1966. Capturas realizadas en la página del Archivo NO-DO 
Conclusiones

En los visionados realizados hemos observado ciertas tendencias en cuanto a la producción arquitectónica y en cómo ésta es representada en el NO-DO. Debido a su vasto contenido entendemos que estamos ante un material susceptible de ser ampliado en estudios posteriores en relación con la producción arquitectónica del momento.

Uno de los primeros aspectos que ha llamado nuestra atención, es que en el NO-DO no se suelen hacer alusiones a fundamentos espaciales dentro de las viviendas. Cuestiones como funcionalidad y otros usos no son contemplados en NO-DO, la arquitectura es un mero utensilio al servicio del régimen que sirve para contentar a los ciudadanos más desfavorecidos. Pareciera como si la arquitectura se planteara como una moneda de cambio, un "calla bocas" frente a la situación que viven.

En cuanto a la autoría de la arquitectura expuesta, es algo que no se suele reparar como aspecto digno de mención, más bien es un dato que suele no contarse. Todo el aspecto resaltado por el comentarista radica en alabar las nuevas aportaciones que hace el régimen, sobre todo en cuestiones de números, tanto en cantidad de viviendas y de personas atendidas, así como del presupuesto total de la obra acometida. En rara ocasión, se contempla el ejercicio del arquitecto como algo digno de ser mencionado, a no ser que corresponda a una de las figuras más relevantes del franquismo. Las descripciones arquitectónicas son tratadas desde la generalidad y también a nuestro modo de ver desde una profunda ignorancia del papel fundamental de la arquitectura. Conforme se avanzan en los años del NO-DO las arquitecturas van tomando una temperatura más acorde con las tendencias de la arquitectura europea, Estados Unidos es un gran referente, que se introduce por el mismo NO-DO y por las revistas propias de arquitectura.

Desde el punto de vista fílmico, observamos que las imágenes que resultan mostradas por medio del corte y montaje, no presentan a nuestro modo de ver ninguna solución ingeniosa o creativa de plano contra plano, salvo en uno de los casos analizados donde hemos observado más cualidades en el tratamiento de la imagen y como estas construyen el discurso.

Otro de los aspectos comunes a los capítulos observados es como es recogida la masa que suele acompañar todas las inauguraciones, el montaje es modificado en pro de reflejar un continuo aplauso que se prolonga más allá de la realidad. Esa masa uniforme donde los rostros individuales quedan ocultos por la rapidez en que la cámara los enfoca, revela una realidad cruel: las subjetividades no importaban, importaba el rebaño, es la masa como un personaje único.

Desde el punto de vista del NO-DO, y evidentemente del régimen, la arquitectura queda reducida al evento inaugurativo, y esto conlleva en la mayoría de los casos a despojarla de todo peso que aporta por sí misma, de alguna manera cada evento inaugurativo sustrae de toda identidad. Lo que nos muestran las imágenes es una arquitectura mediatizada que ejemplifica valores que en ocasiones resultan contradictorios.

Gracias al papel de la arquitectura se hizo posible solventar los problemas inmediatos tras la guerra civil, así como prolongar su tarea con más reflexión y calidad a lo largo de los años del franquismo. Así la producción arquitectónica de estos años se ha revelado en algo más que un mero testigo de la historia, y a nuestro modo de ver se convirtió en una de las protagonistas principales de una época sombría en la historia de España. Los testimonios que aun hoy se conservan de esta época hablan de un buen hacer de arquitectos que no se conformaron y que tuvieron que enfrentarse a muchas cuestiones propias del momento que les tocó vivir, ellos quisieron reconstruir una España que fuese modelo en todos los aspectos. Pero aun así observamos que esta forma de mostrar la arquitectura respondía a una realidad que habla más allá de la propia imagen, y que nos interpela para ser el testigo hostil de un problema de fondo. Siguiendo en este sentido a Sambricio ${ }^{34}$ en su respuesta a Llorens y Piñón, "la arquitectura del franquismo se definió como reflejo de un problema estructural".

\footnotetext{
${ }^{34}$ SAMBRICIO, 1979: A propósito de la arquitectura del franquismo, Carlos Sambricio responde a Tomás Llorens y Helio Piñón, p.25.
} 
Indudablemente la arquitectura supo reflectar de alguna manera la realidad que se está viviendo, y esto hoy puede constatarse gracias al Noticiario Documental. NO-DO. La arquitectura vino a suplir algo que va más allá de la vivienda, daba identidad seguridad y status, fue el esqueleto necesario para restaurar un país roto. La propuesta de "interrogar" a la imagen del NO-DO nos ha permitido como afirma Rafael Tranche: recordar pues, con capacidad crítica y analítica, oponiendo la Historia contra el olvido, sabiendo que todavía quedan muchas preguntas que responder sobre esta arquitectura que fue una de las protagonista del elenco del NO-DO. 
Bibliografía

Alagón Sastre, J.M., Vázquez Astorga, M., "Escuelas de "sabor agrario" los pueblos creados por el Instituto Nacional de Colonización en la zona de La Violada- canal de Monegros I, Aragón”. En Espacio, Tiempo y Educación, Vol. 2, No. 1, pp.281-308, 2015.

Azpiri, A; "La aportación del Colegio Oficial de Arquitectos Vasco-Navarro a la V Asamblea Nacional de Arquitectos, en el año 1959”. En POZO, J.M. (Coord.), Los años 50: la arquitectura española y su compromiso con la historia: actas del congreso internacional, Pamplona 16-17 marzo, Escuela Técnica Superior de Arquitectura, Universidad de Navarra, pp. 2000.

Berguera, I; "Obra Sindical del Hogar: tres décadas de vivienda social” en SAMBRICIO, C., SÁNCHEZ LAMPREAVE, R. (ed.), 100 años de bistoria de la intervención pública en la vivienda y la ciudad. Asociación España de Promotores Públicos de Vivienda y Suelo, Madrid, pp. 121-143, 2008

Alonso Pereira, J.R; Río Vázquez, A.S; “Juan Castañón de Mena. De Regiones Devastadas a los Aprovechamientos Hidroeléctricos", en COUCEIRO NUÑEZ, T. (coord.), I Congreso Pioneros de la Arquitectura Moderna Española: Vigencia de su pensamiento y obra, Madrid, 2014.

Correyero Ruiz, B; "La propaganda turística española en los años del aislamiento internacional", Historia y Comunicación Social, pp.47-61, 2003.

García González, G; "Y Castilla se hizo España...Nacionalización y Representación Cinematográfica de Castilla en el NO-DO”, Ediciones Universidad de Salamanca, 2015.

García Vázquez, C; "La obsolescencia de las tipologías de viviendas de los polígonos residenciales construidos entre 1950 y 1976" en Desajustes con la realidad sociocultural contemporánea. Informes de la Construcción, vol.67, $\mathrm{n}^{\circ}$ extra,marzo, 2015.

González Sáez, J.M; "Ifni en el NO-DO (1943-1969)", Revista Internacional de Historia de la Comunicación, nº2, Vol.1, pp. 62-85, 2014.

Gutierrez Mozo, M.E; Caro Gallego, C; "La arquitectura de la Obra Sindical del Hogar en la ciudad de Albacete: 1941-1981", AL-BASIT 60, Instituto de Estudios Albacetenses "Don Juan Manuel", Albacete, 2015.

Lázaro Sebastián, F.J; "Consideraciones en torno al género documental Español en la época de Franco", Revista Latente, no 9; 2011.

López de Lucio, R; "De la manzana cerrada al bloque abierto" en SAMBRICIO, C. (Ed.), Un siglo de vivienda social 1903-2003 (tomo II), Nerea, Madrid pp.161-166, 2003.

López Dias, J; "Vivienda Social y Falange: Ideario y construcciones en la década de los 40." Revista Scripta Nova, Universidad Nacional de Educación a Distancia, Barcelona, 2003.

López Díaz, J; "La vivienda social en Madrid, 1939-1959”, Espacio, Tiempo y Forma, Serie VII, $\mathrm{H}^{\mathrm{a}}$ del Arte, pp. 297-338, 2002.

Matud Juristo, A; "La incorporación del cine documental al proyecto de NO-DO", Historiay Comunicación Social, pp. 105-118, 2008.

Matud Juristo, A; "La transición cinematográfica oficial franquista: El NO-DO entre la nostalgia y la democracia." Revista Comunicación y Sociedad, Vol. XXII, Núm.1, pp. 33-58, 2009.

Moriente, D; El documental de arquitectura en el cine del franquismo: historia y simbolismo. Anuario del Departamento de Historia y Teoría del Arte (U.A.M),

Vol. XVI, 2004.

Montaner, J. M., Muxí, Z; Habitar el Presente. Vivienda en España: sociedad, ciudad, tecnología y recursos, Ministerio de Vivienda, Madrid, 2006.

Muñoz Carabias, F; "La tradición de lo nuevo: lo paradójico en la arquitectura moderna española”, en COUCEIRO NUÑEZ, T. (Coord.) I Congreso Pioneros de la Arquitectura Moderna Española: Vigencia de su pensamiento y obra, Madrid, pp.639-648,2014.

Pascual Rubio, A; "Alejandro de la Sota: hacia una industrialización de la arquitectura", en COUCEIRO NÚNEZZ, T. (coord.) I Congreso Pioneros de la Arquitectura Moderna Española: Vigencia de su pensamiento y obra: Actas digitales de las Comunicaciones aceptadas al Congreso, págs. 658-670,2014.

Paz, M.A; Sánchez, I; "La historia filmada: los noticiarios cinematográficos como fuente histórica. Una propuesta metodológica". Film-Historia, Vol. IX, No.1, 1999. 
Pérez Escolano, V; "Arquitectura y política en España a través del Boletín de la Dirección General de Arquitectura 1946-1957”, RA: Revista de Arquitectura, No. 16, 2014.

Pérez Moreno, L.C; "Las revistas de arquitectura como medio de estímulo del pensamiento dialógico y crítico: el caso de Nueva Forma en la España de finales de los sesenta", en Jornadas cientificas: Arquitectura, Educación y Sociedad: Hacia una revolución dialógica en la educación critica de la Arquitectura, 2014.

Pérez Moreno L.C; "Claude Parent en Nueva Forma: La recepción de Architecture Principe España" Proyecto, Progreso, Arquitectura, N 11, Año V, Arquitecturas en Común. Universidad de Sevilla, Noviembre, p. 77, 2014.

Berenguel, L; "Vivienda, innovación y proyecto. Necesidades, nuevas tecnologías y estrategias proyectuales" Collegi d'Arquitectes de Catalunya, Barcelona, 2000.

Rabasco Pozuelo P; "Las influencias extranjeras en la arquitectura y urbanismo del Instituto Nacional de Colonización”, Revista Goya, n 336, pp. 254-269, 2011.

Ramírez Martínez, F.E; "Ciencia, Tecnología y propaganda. El NO-DO, un instrumento de popularización de la ciencia al servicio del Estado, 1943-1964", III Jornada d'Història de la Ciència i Ensenyament, Nova Ëpoca/ Vol. 1 (2), pp. 253-261, 2008.

Revenga Domínguez, P.; "Metodologías, interpretaciones y tributos de la Historia del Arte", en PALACIO PRIETO, J.L. (coord.): 90 años de cultura, México, UNAM, 2012, pp. 87-126.

Roch, F; "El sector privado y la construcción de viviendas sociales" en SAMBRICIO, C; (ed.), Un siglo de vivienda social 1903-2003 (tomo II) Madrid, 2003.

Rodríguez Mateos, A; "La memoria de la Guerra Civil en NO-DO “(1943-1959), Revista Historia y Comunicación Social, 10, pp. 179-200, 2005.

Rojo de Castro, L; "La vivienda en Madrid durante la Posguerra 1939-1949,"'en SAMBRICIO, C. (ed), Un siglo de vivienda social (1903-2003) Tomo I. Madrid, 2003.

Sambricio, C.; Madrid, vivienda y urbanismo: 1900-1960, Akal, Madrid, 2004.

Sambricio, C ;(coord.), La vivienda en Madrid en la década de los 50. El Plan de Urgencia Social, Electa, Madrid, 1999.

Sambricio, C; "La vivienda española en los años 50", en POZO, J.M. (coord.), Los años 50: la arquitectura española y su compromiso con la bistoria: actas del congreso internacional, Pamplona 16-17 marzo, Escuela Técnica Superior de Arquitectura, Universidad de Navarra, 2000.

Sambricio, C., Sánchez Lampreave, R. (eds). 100 años de bistoria de la intervención pública en la vivienda y la ciudad, Asociación Española de Promotores Públicos de Vivienda y Suelo (AVS), Madrid, 2008.

Sambricio, C; "A propósito de la arquitectura del franquismo, Carlos Sambricio responde a Tomás Llorens y Helio Piñón." Arquitecturas Bis (n. 27), pp. 25-29,1979.

Tomillo Castillo, A; "La dialéctica entre el progreso y desarrollo en la arquitectura moderna española: El caso de las ciudades sindicales y el tiempo funcional", en COUCEIRO NUNEZ, T. (Coord.) I Congreso Pioneros de la Arquitectura Moderna Española: Vigencia de su pensamiento y obra, Madrid, 2014.

Tranche, R.R; Sánchez Biosca, V; NO-DO: El tiempo y la memoria, Ed. Cátedra/ Filmoteca Española, 8 Edición, Madrid, 2006. 